\title{
PREPARING FOR GLOBALIZED LAW PRACTICE: THE NEED TO INCLUDE INTERNATIONAL AND COMPARATIVE LAW IN THE LEGAL WRITING CURRICULUM
}

\author{
Susan L. DeJarnatt* and Mark C. Rahdert ${ }^{* *}$
}

Table of Contents

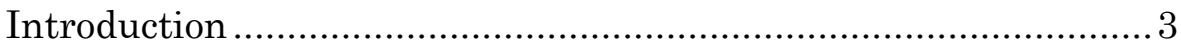

I. Situating LRW within the Globalization Argument .......... 7

A. The Argument for Globalizing the Overall Law Curriculum ............................................................. 7

B. Curricular Proposals to Foster Globalization .......... 9

C. The Case for Globalizing LRW ............................. 14

II. Globalization in Everyday Law Practice: ........................ 18

A Preliminary Survey ................................................ 18

III. Preliminary Recommendations for Globalizing LRW .......23

IV. Globalizing an LRW Assignment .................................. 31

A. General Considerations ................................... 31

B. The DeJarnatt Experiment ................................. 33

V. Topics for Global LRW Problem Development................. 40

A. Family Law ......................................................... 40

B. Commercial Law.............................................. 41

C. Procedural Issues ............................................... 42

VI. Conclusion............................................................ 44

* C 2011, Susan L. DeJarnatt. All rights reserved. Professor of Law, Temple University Beasley School of Law. Thanks to the Philadelphia Bar Association and its director Ken Shear for their support of the survey of the Bar Association membership. We also appreciate the support of the Beasley School of Law and the Honorable Clifford Scott Green Research Fund. We are grateful to the Temple University Measures and Research Center for their help with the survey data. We also thank Sarah Damiani, Audra Price, and George Garcia for valuable research assistance, and Kathy Stanchi and Hether Macfarlane for their comments on earlier drafts. Finally, thanks to Dean JoAnne A. Epps and Associate Deans Jane Baron and Gregory Mandel for their unstinting assistance, encouragement, and advice.

** (C) 2011, Mark C. Rahdert. All rights reserved. Charles Klein Professor of Law \& Government, Temple University Beasley School of Law. For acknowledgments, see supra note *. 


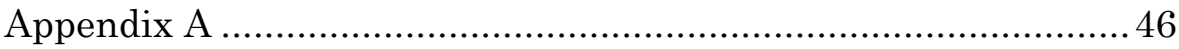

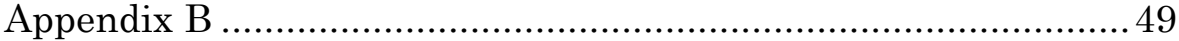

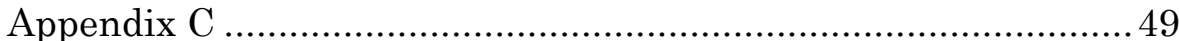

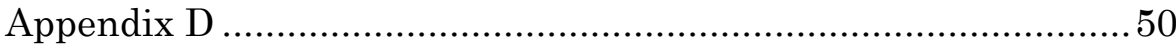

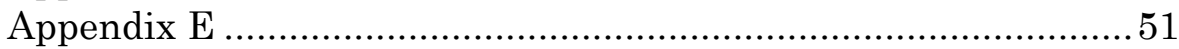

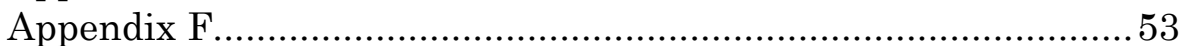




\section{INTRODUCTION}

The case for globalization of American legal education is by now well established. Beginning in earnest in the 1990s and continuing apace to the present, legal educators of many stripes have commented extensively on the rapid globalization of law and the consequent need to globalize legal education. ${ }^{1}$ Their argument in favor of globalizing the law school curriculum has both empirical and normative dimensions. Empirically, it is based on the rapid increase in transnational ${ }^{2}$ interaction (both business and personal) and the resulting development of increasingly complex and increasingly frequent legal problems that raise transnational legal issues as well. ${ }^{3}$ Normatively, it rests on the view that legal education has an affirmative obligation to expose students to other nations, cultures, and legal systems. ${ }^{4}$ Legal educators now widely agree that American law schools need to do more to bring international and foreign law prominently into the law school curriculum. Indeed, the pace of globalization among American law schools has become a flashpoint for institutional competition, with numerous institutions jockeying to lay claim to leadership in this arena. ${ }^{5}$

1. See e.g. H.W. Arthurs, Globalization of the Mind: Canadian Elites and the Restructuring of Legal Fields, 12 Can. J.L. \& Socy. 219 (1997); Larry Catá Backer, Internationalizing the American Law School Curriculum (in Light of the Carnegie Foundation's Report), 14 Ius Gentium 49 (2008); Hiram E. Chodosh, Globalizing the U.S. Law Curriculum: The Saja Paradigm, 37 U. Cal. Davis L. Rev. 843 (2004); Stephen H. Legomsky, Globalization and the Legal Educator: Building a Curriculum for a Brave New World, 43 S. Tex. L. Rev. 479 (2002); James R. Maxeiner, Learning from Others: Sustaining the Internationalization and Globalization of U.S. Law School Curriculums, 32 Fordham Intl. L. J. 32 (2008); M.C. Mirow, Globalizing Property: Incorporating Comparative and International Law into FirstYear Property Classes, 54 J. Leg. Educ. 183 (2004); Mathias W. Reimann, Two Approaches to Internationalizing the Curriculum: Some Comments, 24 Penn St. Intl. L. Rev. 805 (2006).

2. We use "transnational" to refer to those legal disputes that cross borders, involving parties from different countries and/or raising questions involving the application of international or foreign law.

3. See e.g. Backer, supra n. 1, at 52; Legomsky, supra. n. 2, at 479-481.

4. See e.g. Backer, supra n. 1.

5. N.Y.U. Sch. of L., NYU Law, Academics, Areas of Focus, International, http://www.law.nyu.edu/academics/areasoffocus/international/ (accessed May 3, 2011) (follow "Curriculum" hyperlink) (advertising "an unsurpassed array of courses, seminars and colloquia in international, comparative and foreign law"); Georgetown U., Georgetown L., Transnational Programs, http://www.law.georgetown.edu/otp/ (accessed May 3, 2011) (featuring a quotation from Supreme Court Justice Sandra Day O'Connor: ‘Georgetown University Law Center is now situated to be the leading global law center in this country and perhaps the world"). 
Not surprisingly, the case for globalization has spawned a variety of explicit proposals for curricular reform. ${ }^{6}$ These include proposals for both significantly expanding transnationally focused upper-level electives ${ }^{7}$ and incorporating transnational legal issues into the traditional domestic curriculum, ${ }^{8}$ including first-year programs. ${ }^{9}$

Relatively few globalization proposals address the role of globalization in skills courses, and even fewer concern globalization in the Legal Research and Writing ("LRW") curriculum. While some valuable efforts toward globalizing LRW have been undertaken at some institutions, relatively few individuals have considered the case for treating transnational legal issues as a routine component of the standard American LRW course. ${ }^{10}$ To the extent that transnational legal work has entered the LRW arena, it remains an occasional and experimental excursion rather than a mainstay of LRW instruction.

In this Article, we intend to make a case for broader and more systematic incorporation of global legal research into LRW curricula and to demonstrate how it can be accomplished. Part I explains why we think LRW instruction should routinely contain a global component. It also positions our arguments with respect to the matrix of globalization proposals that have been advanced by others. Because our argument is substantially empirical, resting on our belief that everyday legal practice in the United States includes transborder legal issues, we found it desirable to test that premise through some preliminary survey research. Part II describes that research and presents its results, which support our hypothesis that international and comparative law are becoming a routine component of legal practice. Part III describes the

6. See generally e.g. Backer, supra n. 1; Diane Penneys Edelman, Internationalizing Legal Research, Writing, and Oral Advocacy, 24 Penn St. Intl. L. Rev. 829 (2006); Diane Penneys Edelman, It Began at Brooklyn: Expanding Boundaries for First-Year Law Students by Internationalizing the Legal Writing Curriculum, 27 Brook. J. Intl. L. 415 (2002) [hereinafter It Began]; Mirow, supra n. 1; John F. Murphy \& Jeffery Atik, International Legal Education, 37 Intl. Law. 623 (2003); Reimann, supra n. 1; Mary Rumsey, The Skills They Need: International and Foreign Legal Research, 28 Leg. Ref. Servs. Q. 133 (2009).

7. See Backer supra n. 1, at 77; Reimann, supra n. 1; Rumsey, supra n. 6.

8. See generally Mirow supra $\mathrm{n} .1$.

9. Id.; Chodosh, supra n. 1, at 860-868 (proposing the development of textbook complements to add comparative and international perspectives to first-year and advanced courses).

10. There are a few notable exceptions, which we discuss in greater detail below. See infra nn. 31, 32, 44, and accompanying text. 
current efforts at globalization within LRW nationally. Part IV addresses some of the practical challenges involved in incorporating foreign and international law into the traditional LRW course, which it illustrates through discussion of an experiment that Professor DeJarnatt conducted for her 2008-09 and 2009-10 LRW courses. Part V seeks to generalize from Professor DeJarnatt's experience, offering an array of suggested topics drawn from our survey research that other LRW professors can use to generate their own globalized problems and assignments as a regular part of mandatory LRW instruction. Finally, our Conclusion returns to the theme that going forward LRW instruction should include a realistically structured global component so that students are encouraged to view transnational legal issues as an integral component of all legal education.

\section{SITUATING LRW WITHIN THE GLOBALIZATION ARGUMENT}

This Part considers the arguments that have been advanced in favor of globalizing the law school curriculum, various curricular proposals that have been developed to do so, and their implications for adding global content for LRW instruction.

A. The Argument for Globalizing the Overall Law Curriculum

The case for introducing a global component to basic LRW instruction proceeds from the case for globalization of the legal curriculum in general. That general case for globalization has been so thoroughly developed elsewhere that it need not be repeated at length here. ${ }^{11}$ As noted above, that argument has both empirical and normative components.

Empirically, the globalization argument rests on the assertion that cross-border legal interaction is an increasingly substantial component of law practice, one that reflects growth in both global business activity and transborder social interaction. ${ }^{12}$ Where legal transactions and interactions cross borders, they typically acquire a transnational character that implicates the laws of more than one nation, as well as international legal norms.

11. See generally e.g. Backer, supra n. 1; Maxeiner, supra n. 1; Murphy \& Atik, supra n. 6.

12. See generally Mirow, supra n. 1 . 
The result is the globalization of law. Thus, to determine the rights and legal interests of the affected parties, it becomes necessary for skilled practitioners to understand and evaluate a complex set of transnational and/or international legal rules and principles. The advocates of globalization argue that this growth in transnational legal work will accelerate over time, so that before long lawyers of all kinds in the United States will need to be able to function effectively in a transnational legal environment. ${ }^{13}$

Where practice leads, this argument asserts, legal education should follow. In order to prepare rising lawyers for their probable transnational role, law schools must bring a more global dimension into legal education. ${ }^{14}$ Some observers see this step as comparable in its portent for legal education to the movement away from state-based legal instruction and toward a national perspective that spread through American legal education following World War II. ${ }^{15}$ Whatever the strength of that comparison, the advocates of globalization envision a future in which the practice of law is not limited by national borders or confined to a single national legal system.

Normatively, the argument for globalization emphasizes the value to students in being able to put domestic legal issues and their solutions into a larger context, one that exposes students to alternative approaches and different legal cultures. ${ }^{16}$ Exposing

13. See Mirow, supra n. 1, at 183 (quoting John Sexton, "Inevitably, American legal education . . . will undergo a change of kind, one that will recognize that law must be viewed today through a global lens, and that the way we think about and teach law must accept that perspective"); Catherine Valcke, Global Law Teaching, 54 J. Leg. Educ. 160, 165-166 (2004) (arguing that "[t]he difference between a highly globalized economy and a weakly globalized politics is pressing for the emergence of a global law that has no legislation, no political constitution and no politically ordered hierarchy of norms." (quoting Gunther Teubner, Legal Regimes of Global Non-State Actors, in Global Law Without a State foreward (Gunther Teubner ed., Aldershot 1997). "A world composed of diverse political forces, governing agencies and organizations at both national and international levels will need an interlocking network of public powers that regulate and guide action in a relatively consistent way." (quoting Paul Hirst \& Grahame Thompson, Globalization in Question: The International Economy and the Possibilities of Governance 278-279 (Cambridge 1999).)).

14. See generally e.g. Chodosh, supra n. 1; Maxeiner, supra n. 1.

15. Peter L. Strauss, Transsystemia-Are We Approaching a New Langdellian Moment? Is McGill Leading the Way? 56 J. Leg. Educ. 161 (2006); but see Maxeiner, supra n. 1 , at 35 (criticizing the analogy and pointing out that American law schools in the nineteenth century claimed to prepare students for the bar in every state, and that "[i]t is fantastical to think that American law schools might seek to prepare students for the bar of any nation in the world" today).

16. See e.g. Maxeiner, supra n. 1, at 44 (arguing that a globalized legal education is no 
students to other legal systems goes beyond the requirements of practice to inculcate a different conception of law that is not tied to the particulars of a single domestic legal system. In order fully to probe the deeper social significance of law, students need to be exposed to alternative legal systems that rely on different principles, procedures, modes of reasoning, fundamental governmental arrangements, and the like. They also need to understand the process by which competing national legal systems can produce legal synthesis through the development of international law that transcends (and potentially overrides) domestic legal arrangements. This exposure deepens students' understanding of law's underlying philosophical foundations, and it strengthens their grasp of law's role in promoting social development and cohesion. It also exposes them to alternative legal rules and systems, thus enhancing their capacity for critical understanding of domestic legal norms. Without such an understanding, according to this view, students will not be able fully to appreciate the role and rule of law in human social arrangements. ${ }^{17}$

\section{B. Curricular Proposals to Foster Globalization}

The proposals for globalizing the law curriculum are many and varied. They differ significantly from one another in both structure and content, and they are difficult to categorize. While the scope of this article does not extend to a full exposition of all forms of such proposals, some examples follow.

Many law schools have developed programs for study abroad-not just the summer-abroad programs that have been standard fare for decades (that may or may not include instruction in foreign or international law), but also semester-abroad programs, exchange programs with law faculties in other countries, and special legal institutes with a comparative or international focus, including some that are situated in foreign jurisdic-

\footnotetext{
longer subject to the cultural barriers that were once dominant in society, allowing students to focus on the legal cultures that they will likely encounter in an increasingly globalized economy); see also James E. Pfander, Book Review,(reviewing Thomas Main, Global Issues in Civil Procedure (Thomson/West 2006)) (describing the case for globalized Civil Procedure courses by emphasizing how such an approach would lead to a greater understanding of American procedure).

17. See Arthurs, supra n. 1 at 219; Backer, supra n. 1, at 53-54; Chodosh, supra n. 1, at 847-849; Edelman, It Began, supra n. 6, at 416; Rumsey, supra n. 6, at 134.
} 
tions. ${ }^{18}$ For example, Temple operates year-round programs with full-time faculty in Tokyo and Beijing; as well as a summer program in Rome; exchange relationships with the Universities of Cork, Tel Aviv, and Utrecht; and an Institute for International Law and Public Policy in Philadelphia. ${ }^{19}$ One of the more unusual efforts of this kind has been Georgetown's undertaking to create a completely new institution in London that is cooperatively run by several leading world universities and that brings together equal numbers of students from several different nations to study law together for a semester in a setting that is not tied to any single legal culture. ${ }^{20}$

Furthermore, a number of American law schools have attempted to expose students earlier to international and foreign law, often by adding international law offerings to the menu of first-year courses. ${ }^{21}$ Many institutions now include international and/or comparative law somewhere in their first-year curriculum, sometimes as a free-standing course, and sometimes as an element of more traditional first-year courses such as contracts, torts, and property. Pacific McGeorge Law School has been particularly prominent in the effort to develop effective texts that facilitate incorporating international and comparative material into the standard first-year subjects. ${ }^{22} \mathrm{~A}$ few schools have at-

18. Temple Law maintains a study-abroad program in Japan. Temple U. Beasley Sch. of L., Temple Law, International, Tokyo Semester Abroad Program Description, http://www.law.temple.edu/Pages/International/Tokyo_Semester_Abroad_Program_Descri ption.aspx (accessed May 3, 2011). Yale allows students to choose a semester-abroad program by region. Yale L. Sch., International Law, http://www.law.yale.edu/documents/pdf/ Admissions/13275Internat.pdf (accessed May 3, 2011). American University also maintains a variety of choices for its students when it comes to semester-abroad programs. Am. U. Wash. College of L., Study Abroad Programs, http://www.wcl.american.edu/ studyabroad/ (accessed May 3, 2011).

19. See Temple U. Beasley Sch. of L., Temple Law, International, Study Abroad and Exchange Programs, http://www.law.temple.edu/Pages/International/International_Study _Abroad.aspx (accessed May 3, 2011).

20. Georgetown U., Georgetown Law, Transnational Programs, 2011 London Summer Program, http://www.law.georgetown.edu/intl/london/ (accessed May 3, 2011).

21. See e.g. Murphy \& Atik, supra n. 6 (describing transnational law course required by University of Michigan and offered as an elective in the first year; recommending that schools require public international law as a first-year course). Temple has added an international law elective to its first-year curriculum. Temple U. Beasley Sch. of L., Temple Law, International, IILPP Degrees Abroad, http://www.law.temple.edu/Pages/ International/IILPP_Degrees_Abroad.aspx (accessed May 3, 2011).

22. Pacific McGeorge is developing a multi-volume series of global issues casebooks that are intended

"to facilitate the introduction of international, transnational and comparative law issues into basic law school courses. The goal of this series is to ensure that all law 
tempted more radical curricular revision. McGill University Law School in Canada is among the most aggressive of these institutions. Situated in a civil-law province (Quebec) within a predominately common-law national legal culture (Canada), McGill has tried to blend these two perspectives into a single transnational approach that is not explicitly rooted in any single domestic legal tradition, but that trains students to navigate multiple legal cultures. ${ }^{23}$ Most schools that have undertaken these and other globalization-oriented reforms have acknowledged that the shift can demand substantial faculty resources, but they generally report both positive student reactions and faculty satisfaction with the general enrichment of the curriculum. ${ }^{24}$ Curricular globalization, they report, is both dynamic and energizing for all involved.

The intensity of the arguments for globalization varies from legal context to legal context. It has probably attained its greatest force in business and transactional areas of law, where the empirical case for globalization is particularly strong. ${ }^{25}$ But the case for greater globalization has been advanced in almost all areas, including all of the subjects we traditionally regard as foundational (and hence usually mandatory) in the American legal

school graduates have sufficient familiarity with the growing impact of non-domestic sources of law, and the growing potential for transnational legal transactions and disputes, to function in an era of increasing globalization. In addition, introduction of International, Transnational and Comparative Law materials can enhance the students' understanding of domestic law. The philosophy behind this series may be best summarized by Justice Stephen G. Breyer's statement that '[t]his world we live in is a world where it is out of date to teach foreign law in a course called Foreign Law."”

W. Academic Publg., Global Issues Series, http://www.westglobalissues.com/ (accessed May 3, 2011) (quoting Franklin A. Gevurtz, Series Editor, and Distinguished Professor and Scholar, University of the Pacific, McGeorge School of Law).

23. Rosalie Jukier, Transnationalizing the Legal Curriculum: How to Teach What We Live, 56 J. Leg. Educ. 172, 174 (2006) (describing the McGill curriculum, which "seeks to incorporate transnationalism into the curriculum by freeing the study of law from jurisdictional or systemic boundaries"). Today McGill's efforts have culminated in classes such as "Social Diversity and the Law," a class focused on the development of international human rights. McGill U., Course Offerings 2010-2011, http://www.mcgill.ca/files/lawstudies/Course_offerings_2010-2011.pdf (accessed May 3, 2011).

24. See e.g. Jukier, supra n. 23, at 180. Jukier notes that McGill students and professors are required to have sufficient language skills so that they can understand oral and written English and French. Professors need to have or to develop expertise in both civil and common law and need to create teaching materials suitable for this approach.

25. See Hannah L. Buxbaum, National Jurisdiction and Global Business Networks, 17 Ind. J. Global Leg. Stud. 65 (2010); Laurel S. Terry, The Legal World is Flat: Globalization and Its Effect on Lawyers Practicing in Non-Global Law Firms, 28 Nw. J. Intl. L. \& Bus. 527 (2008). 
curriculum. Even litigation has taken on globalized attributes. ${ }^{26}$ Law schools that view themselves as leaders in the globalization campaign typically emphasize a broad range of curricular developments in their schools that collectively expose their students to global legal issues in a wide array of settings. ${ }^{27}$

One distinguishing feature concerns the degree of exposure to foreign and international law. Many proposals advocate "thin" treatment that is meant only to sensitize students to global issues, while others seek relatively "thick" immersion that offers some students a chance to develop substantial transnational competence, perhaps even expertise, in foreign and/or international law. ${ }^{28}$ Advocates of the thin approach usually favor broad exposure among students that can be undertaken without upsetting the many other curricular objectives in legal education. ${ }^{29}$ Thick

26. See Mirow, supra n. 1. Ralph Steinhardt has authored a case book on what he calls "intermestic law," that is the "the variety of foreign, domestic, and international sources from which domestic courts derive a rule of decision, as well as the logistical difficulties they face when rules, attorneys, clients, and issues show little if any respect for physical or political borders." Ralph Steinhardt, International Civil Litigation: Cases and Materials on the Rise of Intermestic Law v (LexisNexis 2002). Temple has been actively involved in providing advocacy training to prosecutors from China. See also Scott L. Cummings, The Internationalization of Public Interest Law, 57 Duke L.J. 891 (2008) (examining the impact of globalization on the work of public interest lawyers).

27. Georgetown boasts an "array of course and seminar offerings at the Law Center dealing with transnational, international, and comparative law in many forms." Georgetown U., Georgetown Law, Transnational Programs, http://www.law.georgetown .edu/otp/ (accessed May 3, 2011). Columbia claims to be far ahead of the pack when it comes to creating a curriculum focused on international issues, stating, "Columbia Law School has been 'internationalizing' U.S. legal education since its founding before the American Civil War." Colum. L. Sch., International Programs, http://www.law.columbia .edu/center_program/intl_progs (accessed May 3, 2011).

28. Reimann, supra n. 1 (contrasting the approach of "presenting occasional comparative, international or transnational perspectives in all (or at least most of ) the courses in a piecemeal fashion" with requiring a separate, more in depth course on transnational law for all students). Catherine Valcke emphasizes the difference between adding international and comparative perspectives to "enrich studies in domestic law" and global law teaching that is intended to enable students "to think like global lawyers." Valcke, supra n. 13, at 168-169. For the former, add-ons to existing courses can suffice. For the latter, Valcke proposes intense study, preferably at the graduate level and preferably including study within a foreign system, providing experiential learning of the foreign legal system for the student. Id. at $176-178$.

29. Hiram Chodosh advocates the development of global "complements" to existing courses in order to "domesticate comparative, transnational, and international law and to globalize domestic legal disciplines." Chodosh, supra n. 1, at 861. The complements would be short and would allow professors with a domestic focus to develop their expertise while allowing a modest and efficient addition of new content. Id; see also Legomsky, supra n. 1, at 486-487 (proposing that law schools adopt a "pervasive strategy," integrating an international law component into every course to ensure that all law students are exposed to international and comparative law principles). 
approach advocates, in contrast, observe that only a detailed understanding of alternative legal systems enables the sort of astute, context-based, nuanced critical understanding that globalization is supposed to promote. They consequently advocate development of curricula that enable transnational specialization by a select group of law students who wish to concentrate on global legal questions. ${ }^{30}$

Another point of difference among the proponents of globalization concerns whether the global materials are "integrated" into the presentation of domestic doctrine, or are treated as "supplemental" topics that are added to domestic coverage. ${ }^{31}$ Once again, there are arguments for both approaches. Those who seek integration stress the growing importance of global legal issues and want to avoid the risk that globalization will be seen by students as a "sideshow" or a "frill" that is not central to legal understanding. ${ }^{32}$ Those who support supplemental treatment stress the continuing centrality of domestic law to the bulk of legal issues and the likelihood that global concerns will arise only in select situations. ${ }^{33}$

Still another variation in approach concerns whether the globalization component of legal education should be "elective" or "mandatory." Elective approaches stem from the recognition that global legal questions comprise only one among many valuable perspectives for legal education. In this view students should be free to choose whether to specialize in topics that include transnational dimensions, or to construct their legal education around

30. Valcke provides as an example of immersion within a foreign system a package of different courses in the various aspects or fields of one and the same foreign system taught by instructors trained in that system, which package might combine experiential and didactic courses. So students interested in specializing in, say, Japanese law might be offered the option of an upper-year "stream" in Japanese law ... that would comprise a certain number of courses in the procedural, substantive, and jurisprudential aspects of the Japanese legal system. Upon completing such a package of courses, students could realistically be expected to have acquired a meaningful understanding of the way Japanese lawyers think.

Valcke, supra n. 13, at 178. Mary Rumsey advocates for an upper-level course in foreign and international legal research that is taught by law librarians. Rumsey, supra n. 6, at 138.

31. Larry Catá Backer distinguishes between approaches that aim to infuse international perspectives into all courses and those that instead add courses with an international focus to the existing curriculum. Backer, supra n. 1, at 76-81.

32. Id. at 49 .

33. Reimann, supra, n. 1 , at 807. 
alternative ways of synthesizing law. ${ }^{34}$ Elective approaches, moreover, usually lend themselves to deeper immersion in global legal questions for students choosing to pursue a specialty. In contrast, those who favor mandatory approaches emphasize the probable centrality of globalization to the law of the future, and hence the need for all students to develop an awareness of global dimensions in law. ${ }^{35}$

Additional differences among the various proposals concern the relationship of globalization to programs for study abroad; 36 connections with existing programs that educate foreign students; the creation of unique "institutes" or "centers" within the law school's institutional structure (or sometimes elsewhere in the university) to develop, staff, manage, and operate such programs; needs and opportunities for "specialization" by faculty and "concentration" by students, and other matters. ${ }^{37}$ With perhaps the single exception of McGill University's extraordinary program, however, hardly any proposals seek entirely to supplant instruction in domestic law. Rather, they accept the presumptive validity of the existing curriculum's primary focus on domestic legal doctrines and institutions, which the proponents seek to enrich by incorporating a global perspective.

\section{The Case for Globalizing LRW}

For LRW instruction, with its emphasis on developing skills for practical lawyering, the empirical component of the globalization argument naturally gets heavy emphasis. It rests on the fundamental premise that, as transnational legal interactions increase, and the lines between domestic and foreign-

34. Chodosh has suggested that material focused on international perspectives of traditional American law courses should be developed to allow for possible electives centered on these perspectives. See Chodosh, supra n. 1, at 861. Rumsey believes that requiring law students to take courses in international law may be too ambitious, but that offering an elective is reasonable. See Rumsey, supra n. 6, at 138.

35. Mirow states that instruction in the international legal principles of property should begin within the first year of law school, arguing that many American precedents were developed through international channels that remain relevant today. See Mirow, supra n. 1, at 188. Reimann believes that making such courses mandatory is the only tenable way of exposing students to international law. See Reimann, supra n. 1, at 806.

36. Backer identifies immersion as a emerging approach where the emphasis is on students studying the law of another country in that country and in its language. Backer, supra n. 1, at 83-88.

37. Id. 
international law blur, the need for attorneys who can function effectively in a global legal environment also increases. Dealing with foreign and international law no longer remains the specialty of a select few practitioners but is becoming the norm for the ordinary lawyer. As the twenty-first century deepens, legal practice that is confined to issues of domestic law will steadily diminish, to be replaced by practice that involves both domestic and global components, and that requires attorneys who are skilled at moving seamlessly between them. Thus, it becomes necessary to prepare students for this role by exposing them to the characteristics of transnational practice, and by affording them opportunities to utilize transnational law in both oral and written legal analysis. ${ }^{38}$

Diane Edelman and other innovative LRW scholars have argued that these current and anticipated changes in legal practice support the development of a more global focus in LRW instruction. ${ }^{39}$ If lawyers must be skilled at incorporating transnational legal matters into their work, they must also be able to engage in research on foreign and international legal issues, to incorporate the results of that research into their legal reasoning, and to communicate effectively in writing about transnational legal questions. The requisite skills for doing so, moreover, are sufficiently distinct from domestic legal research and reasoning that they cannot be acquired either by osmosis or by simple extrapolation of domestic techniques to a transnational plane. ${ }^{40}$ Consequently, rising twenty-first century lawyers will need explicit exposure to, and instruction in, the basic LRW skills that are fundamental to a transnational legal practice. The best way to accomplish this objective is to introduce a global component into the LRW instruction that law students receive.

38. See e.g. Colin B. Picker, The Top 10 Reasons Why International, Comparative and Foreign Law Are Vital to a Kansas City Attorney, 16 KC Counselor 10 (May 2007) (providing "ten good and tangible reasons that show why a local attorney should know or consider [international, comparative, and foreign] law as part of her practice and legal mind-set"); see also Linda Karr O'Connor, International and Foreign Legal Research: Tips, Tricks, and Sources, 28 Cornell Intl. L.J. 417 (1995) (arguing that international and foreign law are now unavoidably part of any general legal researcher's work and offering guidance to the resources necessary to effective research in these areas).

39. Edelman, It Began, supra n. 6; Frank A. Gevurtz, Incorporating Transnational Materials into Traditional Courses, 24 Penn. St. Intl. L. Rev. 813 (2006); Rumsey, supra n. 6.

40. Edelman, It Began, supra n. 6; Gevurtz, supra n. 39; Rumsey, supra n. 6. 
This essentially empirical case is reinforced by some of the normative considerations discussed above. If, as many have argued, exposure to international principles and the law of other legal cultures provides an important perspective on the development and operation of domestic law, then training in basic skills needed to acquire further knowledge of foreign and international law surely facilitates development of that perspective. ${ }^{41}$ This normative interest attains particular force in institutions where other topics in the legal curriculum (especially those taught in the first year) now include a global legal component. Where globalization is taking place in a wide range of first-year doctrinal courses, it would seem anomalous for LRW instruction to be omitted from that effort.

With ever-increasing attention being paid to internationalizing the first-year curriculum, LRW should not be left behind. LRW professors should not jump on the bandwagon just for the sake of company. But this bandwagon is much more than just a fad-it is the future. Students will regard international and comparative law as part of their basic toolkit only if they actually use these resources. Moreover, LRW will only be seen as part of the mainstream if it incorporates law widely used in other subject areas. $^{42}$

Including exposure to foreign and international law in LRW reinforces the importance of these topics elsewhere in the curriculum. Indeed, if American legal education is truly serious about the globalization of law, we should demonstrate that belief by including global legal research in the toolkit of essential skills that students are expected to acquire. Doing so sends the message that these skills are an important component of competent and responsible lawyering. Failing to do so sends the opposite message: global skills are not really needed for professional competence. Lawyers who have been trained in the process of acquiring

41. Edelman, It Began, supra n. 6; Gevurtz, supra n. 39; see also O'Connor, supra n. 38, at 418-420 (identifying differences between American and foreign legal research sources and their significance for practitioners); Rumsey, supra n. 6, at 134 (describing globalization of legal practice and its effect on legal education).

42. Susan Liemer explores the value for LRW professors of designing LRW problems that rely on the professor's doctrinal or practice interests. She notes that "a stronger sense of multiple cultural perspectives will prepare students better for legal careers that are more likely than ever before to include international work." Susan P. Liemer, Many Birds, One Stone: Teaching the Law You Love, in Legal Writing Class, 53 J. Leg. Educ. 284, 287 (2003). 
information about foreign and international law and incorporating that knowledge into their client representation will be better able to do so in practice. Lawyers who remain ignorant of global legal skills will be at a competitive disadvantage, one that deepens as the globalization of legal practice progresses. ${ }^{43}$

Additionally, bringing globalization into LRW training weaves together two disparate strands of legal education reform. During the same period that has seen the proliferation of globalization proposals mentioned above, another reform movement in legal education has stressed the need for law schools to reinvigorate their emphasis on professional competence. This approach gives students more opportunities to put their legal knowledge to work in either simulated or actual practice settings, and to give standards of professional conduct greater prominence. This movement is prominently represented in the ABA's MacCrate Report $^{44}$ and the more recent proposals for revamping the legal curriculum advanced by the Carnegie Foundation. ${ }^{45}$ As Professor Backer recently observed, the Carnegie-MacCrate proposals for reform have largely neglected globalization, and the globalization proposals for reform have largely neglected the CarnegieMacCrate emphasis on professional experience. ${ }^{46}$ Globalizing LRW instruction would create an opportunity for bringing these two strands of legal education reform closer together.

As we began to map out ideas for a globalized LRW course, we realized the extent to which our case for globalizing LRW depends on assumptions about the increasingly global nature of typical legal practice. But when we surveyed the relevant literature,

43. Mark Rahdert has written about the need to improve the education in comparative constitutional advocacy, stating,

Unless comparative research techniques and comparative analysis achieve greater prominence in American legal education, advocates will lack the skills that are needed to make sophisticated and effective comparative constitutional arguments, and the role of comparative precedent will remain largely cosmetic. With significant change in legal education, the forces of globalization and constitutional convergence, as well as the growing sophistication of foreign constitutional law, promise both greater and more effective use of comparative constitutional analysis in the future.

Mark C. Rahdert, Comparative Constitutional Advocacy, 56 Am. U. L. Rev. 553, 665 (2007).

44. ABA Sec. of Leg. Educ. \& Admis. to B., MacCrate Report, http:// www.abanet.org/legaled/publications/onlinepubs/maccrate.html (July 1992).

45. See generally William M. Sullivan et al., Educating Lawyers: Preparation for the Practice of Law (Jossey-Bass 2007).

46. Id. at 99-105. 
we found fairly little hard evidence documenting the asserted trend toward globalization in practice. ${ }^{47}$ Transnational legal developments, and the growth of trans-border commercial and social interaction, certainly provide logical support for inferring a growth in transnational practice among American lawyers. But while many commentators have often asserted a trend toward globalization, ${ }^{48}$ no one seems actually to have demonstrated its presence in contemporary legal practice. In order partly to address this lacuna, we determined to conduct a survey of practitioners in our institution's most immediate legal market, the Philadelphia bar, to see whether, and how much, the lawyers in our immediate vicinity actually encounter foreign and international legal issues. The next section describes that survey and presents its results.

\section{GLOBALIZATION IN EVERYDAY LAW PRACTICE: A PRELIMINARY SURVEY}

We began this project with the theory that issues of foreign and international law are no longer the sole province of the specialist. Indeed, our argument for globalizing LRW instruction rests heavily on that proposition. But while there is widespread allusion to the progressive globalization of typical legal practice, there is surprisingly little actual empirical evidence. To test our hypothesis, we decided to survey the active members of the Philadelphia Bar Association to determine whether they regularly face the need to consider such issues.

We chose Philadelphia principally because our home law school is located there, and the region is a primary market for our graduates. But we believe that Philadelphia's bar represents a fairly good sample for our purposes. Philadelphia is not known as

47. In answering "Why international law?," Edelman cites the increased importance of international issues in our lives, but with few specifics. Edelman, It Began, supra n. 6, at 415-416. Similarly, Mirow appears satisfied that "legal education around the globe" is changing and hence domestic legal education should change to "accept that perspective." Mirow, supra n. 1, at 183 (quoting John Sexton, The Academic Calling: To Global Common Enterprise, 51 J. Leg. Educ. 403, 403 (2001)). Several authors agree that globalization was inevitable due to expanding trade, with Arthurs going so far as to predict the "hollowing out" of corporate Canada as a result. Arthurs, supra n. 1, at 226. Yet for each of these assertions, no documented evidence of the expansion of international law into domestic legal markets was available.

48. See e.g. Edelman, It Began, supra n. 6, at 415-416; see generally e.g. Mirow, supra n. 1. 
a center for international legal work, although it has a diverse legal community including many major corporate law firms that maintain offices in other countries. Unlike Washington or New York, Philadelphia is neither a world capital nor a major international financial center. Its legal community thus focuses predominantly on the local region and the domestic market. Presumably, most lawyers practicing in the region serve primarily local or regional clients with legal needs that are fairly typical of those in any large United States metropolitan area.

At the time of our survey, the Philadelphia Bar Association had 10,740 active members. This seemed to us to be a large enough pool to yield a potentially reliable response. Accordingly, we contacted the Bar Association, which generously agreed to share its membership address list with us. The Association also gave us valuable assistance in assembling a focus group of lawyers, with whom we met to review and critique the contents of our proposed survey. After reviewing the survey with this group and making several revisions based on their suggestions, we mailed the survey to all active Bar Association members in February 2009.49 We received 1,050 tabulated responses, representing a 9.69 percent response rate, which seemed sufficient for our purposes and within the range of what colleagues experienced in survey research identified as an acceptable response. With technical assistance from our university's Measurement and Research Center, ${ }^{50}$ we tabulated the responses in various ways, some of which we have presented in several tables attached to this Article as Appendices B-F.

The most informative result from the survey is that a substantial majority, ${ }^{51} 67.5$ percent, of the respondents reported that

49. The relevant text of the survey is attached as Appendix A, Survey of International and Comparative Law Experiences in Practice ("survey").

50. We received an additional twenty-two replies after the survey responses had been submitted to the Measurement and Research Center for tabulation. The additional replies are not included in the tabulations but have been included in the stories the respondents shared that are compiled in Appendix F.

51. Sixty-seven and one-half percent of the respondents answered yes to the question: Have you ever worked on a legal matter, including any that required consultation with local foreign counsel, that required you to know something about:

Foreign law (that is, the law of another country)

International law (e.g. UN Conventions, WTO decisions, treaties signed by the United States)

Both

Neither 
they had worked on a legal matter that required them to know something about foreign and/or international law. ${ }^{52}$ This response (see Appendix C) supports our original thesis that international and comparative legal issues have become part of the general practice of law. The respondents, moreover, represent a fairly wide array of practitioners in terms of demographics. ${ }^{53}$ The median year of graduation was 1991 (18 years in practice) with 24 percent of respondents in practice for five years or less, 30 percent in practice from five to twenty years, and 46 percent in practice more than twenty years. The majority of respondents identified themselves as lawyers in private practice, but we also received responses from civil government and public interest lawyers, prosecutors and public defenders, and corporate in-house lawyers. Very few, only 3 percent, described the geographic base of their practice as international. The remaining respondents were fairly evenly divided in identifying Philadelphia (30.8 percent), the region (37.7 percent), and the United States (28.1 percent) as their geographic client base. Tables summarizing the demographic information we collected are included in Appendix B.

The survey also supports the conclusion that the need to know foreign or international law, though regular, is not a frequent or routine occurrence for this population of lawyers. We tried to gather more details about how often the respondents needed to know about foreign law; how often international law; and how often both. Of the respondents identifying such a need, about half (48 percent) said they needed to know only foreign law, defined as the law of another country. Eleven percent identified only international law, and 41 percent replied they needed to know both foreign and international law. ${ }^{54}$ The responses concerning the type of law respondents needed to know are included in Appendix D.

We also asked how often the need to know about foreign and international law has arisen within the last year. Nearly 83 percent said from one to five times and only 9 percent said more than ten times. During the last five years, approximately 47 percent

\footnotetext{
Infra app. A, question II(1).

52. Survey answer to question II(1), infra app. A.

53. We do not claim to have a statistically valid sample that precisely represents the practicing bar in Philadelphia. We see the survey results as informative, not as proof of a scientifically established truth.

54. Survey answer to question II(1), infra app. A.
} 
said the need had arisen one to five times, and 17 percent said more than ten times. In an effort to determine whether the need to know about foreign or international law is growing, we also asked about the frequency of need to know foreign and international law more than five years ago. Approximately 37 percent again said one to five times, and 15 percent said over ten times. Data concerning the frequency of foreign and international legal issues appear in Appendix E.

We believe these results show that Philadelphia lawyers regularly have the need to know something about the laws of another country or international law, but that the need does not arise with great frequency for most lawyers. Somewhat contrary to our expectations, the results also tend to show that the need has remained relatively steady over the past decade. We predicted a gradual increase in frequency over that period, but the data we collected fail to substantiate such a development.

Among the most interesting aspects of the survey responses were the respondents' descriptions of the problems they confronted. Before constructing our survey, we informally solicited information from friends and contacts within the Philadelphia legal community about their foreign or international legal work. The stories they shared motivated us to pursue more systematic documentation of the typical lawyer's experience with foreign legal issues. Family law specialists told us about international child custody disputes and the frequent need to evaluate the risks of international travel with children whose parents are involved in divorce proceedings. Personal injury lawyers told of clients who were injured abroad. Estate lawyers told us they faced issues regarding tax and probate laws of other countries in situations in which the decedent or heirs might be foreign nationals or the estate property was located overseas. One of our contacts even told us about a municipal court landlord-tenant case that turned into a federal lawsuit involving the Foreign Sovereign Immunities Act because the lessee was a foreign government. We were intrigued by the variety of problems and issues this informal inquiry revealed, and we decided to try to find out more comprehensively about the types of legal issues that might arise.

To do so, the survey invited respondents to give examples of issues that had required them to confront international or comparative law. Over 140 respondents provided us with further details, and they include a wealth of examples covering a wide array 
of issues and countries. ${ }^{55}$ One reported the need to consider the impact of Shari'a law on the sale of a house to a woman separated from her husband where the husband lived in a country honoring Shari'a marriage law. Another had to determine whether a French national living in the United States could donate to French political candidates. Other respondents confronted whether Chinese grandchildren of a United States decedent were entitled to share as remaindermen under the grandmother's trust; the effect of European Union law on an underground storage tank; and how Chinese reduction-in-force law affected an independent contractor based in Hong Kong. One respondent needed to determine Scotland's statute of limitations on a repressed memory claim.

Respondents reported a need to ascertain the validity of a claim for personal injuries resulting from a camel ride in Egypt; the right to shelter under international treaties; and the validity of a power of attorney executed in Brazil. Another reported the need to determine how cross-border transport of gold was affected by the law of the countries involved. One respondent had to determine the validity of a judgment under Indonesian law and whether it was entitled to comity in the United States; others needed to determine French pension rights in order to determine strategy in a divorce action, and the impact of the real estate law of Vietnam. Numerous respondents mentioned environmental issues, intellectual property, trade, tax, and corporate issues as well. Others mentioned issues of forum non conveniens, application of international arbitration, enforceability of judgments, service of process, and other procedural questions raising international or foreign components. A summary of issues described by our respondents is contained in Appendix F.

The breadth of potential issues seems limitless. And it is clear from the illustrative examples that attorneys who are not international specialists confront such issues on a regular basis. It was evident from the survey responses that the bulk of our respondents encounter foreign and international law occasionally and unexpectedly, in the course of representing fairly "ordinary" clients on apparently "ordinary" matters that primarily involve domestic United States law. They undertake work on what seems

55. Survey answer to question II(6), infra app. A. See infra appendix F for a table organizing the answers. 
initially to be a fairly routine business, property, tax, personal injury, or domestic relations matter, only to discover that it contains a foreign or international component they may not have initially anticipated.

We think that these survey results support and reinforce the case for globalizing LRW. Initially, they substantiate the premise that American law is becoming globalized. Equally, they support the view that globalization is emerging as a regular component of everyday legal practice. Lawyers practicing in a wide range of settings encounter issues of foreign and international law in the course of representing their typical clients on typical matters. The need to know foreign law is thus a regular and recurrent component of legal practice for the typical Philadelphia lawyer practicing in the first decade of the twenty-first century.

\section{PRELIMINARY RECOMMENDATIONS FOR GLOBALIZING LRW}

So how is this introduction to non-United States law best accomplished, and what skills regarding non-United States law should LRW courses convey? The most obvious one is the ability to identify, locate, and acquire information about relevant foreign and international law. Doing so effectively calls for research skills beyond those that students acquire through working with domestic legal resources.56 Mary Rumsey explains that students must go beyond their dependence on domestic databases to learn how to access the different resources relevant to international and comparative law. ${ }^{57}$ She describes, as examples, the need to find customary international law through treaties, laws of other nations, diplomatic correspondence, and scholarly works, and she points out that civil law research requires much more emphasis on statutes and scholarship than on the case law that plays such a dominant role in American legal analysis. ${ }^{58}$ While there have been significant advances in access to foreign and international

56. Rumsey points out that the research tools necessary to conduct effective domestic legal research do not exist in the foreign legal context, and without exposure to these tools, students will not acquire the research techniques necessary to tackle modern legal issues. Rumsey, supra n. 6, at 136-137.

57. $I d$.

58. $I d$. 
legal sources, there are still substantial barriers, ${ }^{59}$ and the research methods needed to obtain these resources can be different (in ways either subtle or stark) from those that apply to domestic law. Although much foreign and international material is available either in library hard copy or through the Internet, finding it is rarely as easy as, for example, searching the United States Code or locating relevant cases in federal and state reporters. One challenge, of course, is finding relevant material from nonEnglish speaking foreign legal institutions in reliable English translation. ${ }^{60}$ Other challenges include developing the ability to identify relevant lawmaking and/or law-applying institutions, acquiring a satisfactory understanding of their decision-making practices and procedures, and assessing the scope of their legal authority. ${ }^{61}$ A related challenge concerns understanding the legal hierarchies of authority that operate internationally or in foreign states, which often differ from those to which we are accustomed in the United States. ${ }^{62}$ These difficulties vary in intensity depending on the nature of the issue, the laws that potentially apply, the identity of the relevant foreign or international legal system(s) involved, and the character and complexity of the relevant foreign or international legal sources. Even at a minimum, however, they are sufficiently distinct from domestic legal research to call for additional instruction.

In addition to these research issues, there are further challenges involved in putting foreign and international legal principles to work. It may not be immediately apparent where and how foreign or international law should be integrated into the analysis of a domestic legal problem. Incorporation of foreign and international rules and principles will require skills of synthesis and distinguishing that are distinct from traditional domestic legal reasoning, and they may require appreciation of important differences in foreign/international legal, political, or perhaps even cul-

59. Id.; see also O'Connor, supra n. 38, at 421-423.

60. O'Connor, supra n. 38, at 422-423; Rumsey, supra n. 6, at 136-137.

61. O'Connor, supra n. 38, at 419, 421-423. Civil law jurisdictions, for example, lack U.S. tools like citators and case digests because of the reduced role cases play in systems that do not adhere to stare decisis. Rumsey, supra n. 6, at 137 . O'Connor provides a wealth of information about useful sources for international and foreign law research. O'Connor, supra n. 38, at 420-451; see also Rumsey, supra n. 6, at 140-142.

62. O'Connor, supra n. 38, at 419; Rumsey, supra n. 6, at 139. 
tural context. ${ }^{63}$ International legal rules often play a complex role in domestic law, presenting issues of interpretation and enforceability that do not easily fit within traditional domestic United States legislative, administrative, and judicial legal structures. ${ }^{64}$ Integration or application of rules from foreign nations may be even more complex, especially where those systems are substantially different from our own. ${ }^{65}$ Additionally, there may be discrepancies between the form and function of foreign or international law that affect their proper application. These differences in character and context, moreover, generate unique challenges for the deployment of foreign and international legal principles in persuasive legal reasoning before domestic courts or other decision-making tribunals. ${ }^{66}$

When one moves from the domestic to the international plane, the complexities multiply. Those complexities require a more elastic approach to representation, in which the lawyer, counselor, or advocate shifts perspectives, techniques, and even sometimes roles, as she moves from one legal regime or setting to another. International law has its own conventions, its own legal hierarchies, and its own institutions, all of which are both proliferating and rapidly evolving. Mastering this domain calls for a

63. "Unlike domestic law, where the student must grapple with the constitutionstatute-case law hierarchy, the student of international law must become comfortable with treaties as well as the more amorphous concepts of 'customary international law' and 'general principles of law." Edelman, It Began, supra n. 6, at 419. "International law, particularly international customary law, requires a wholly different type of research from that used in domestic law. To show the existence of a rule of customary international law, a lawyer musters examples of state practice, whether manifested in treaties, national legislation and court cases, diplomatic correspondence, or other miscellany." Rumsey, supra n. 6, at 136-137; see also id. at 147 n. 31 (describing role of court decisions in civil law countries).

64. Id. at 134. Imagine, for example, an LRW problem that involved the asylum claim of a woman escaping from an abusive partner. Such a problem might require the students to consider the domestic laws of the woman's home country as well as United States law on asylum. International principles of human rights conceivably could also come into play.

65. Id. at 147 n. 32; see also O'Connor, supra n. 38, at 419-420.

66. See Samuel P. Baumgartner, Transnational Litigation in the United States: The Emergence of a New Field of Law, 55 Am. J. Comp. L. 793, 799-805 (2007) (reviewing Gary B. Born \& Peter B. Rutledge, International Civil Litigation in the United States (4th ed., Wolters Kluwer 2007)) (discussing the distinct challenges transnational litigation presents, including the need to understand foreign procedural and well as key substantive law, along with understanding the foreign institutions in which those procedural rules arose); see also Carole Silver, Educating Lawyers for the Global Economy: National Challenges, _ Kyung Hee U. L. Rev. _ _ (forthcoming 2009-2010) (emphasizing the need for "global legal literacy" including "four elements: language, cultural fluency, an appreciation for the role of lawyers, and law itself"). 
transformation of perspective and a temporary shedding of domestic legal practices and habits. It also requires acquisition of new legal concepts and precepts, even a different legal language. As students who have participated in the Jessup Moot Court competition can attest, international legal skills involve a great deal more than simple extrapolation from domestic training. ${ }^{67}$

From these observations it follows both that the commitment to globalized legal instruction should include some form of global LRW instruction, and that the introduction of a global component will require some adjustment in the way LRW is taught. Several law schools have experimented with introducing foreign and international issues into basic LRW instruction. ${ }^{68}$ Some have responded to these arguments by creating either upper-class elective seminars with a global LRW focus, ${ }^{69}$ or by creating a specialized foreign/international section of the basic LRW course. ${ }^{70}$ Typically, this has been accomplished in a largely ad hoc fashion through the creative efforts of individual instructors, who sometimes offer a special "international" section of the basic LRW course. ${ }^{71}$ Additionally, LRW professors whose primary responsibility is to educate foreign students have naturally gravitated toward incorporating global dimensions in their problems and assignments. ${ }^{72}$ Faculty specializing in teaching legal English have

67. Jessup has been described as teaching students a "mastery of the sources of international law that are applied by the ICJ." Edelman, It Began, supra n. 6, at 419.

68. E.g. Touro College Jacob D. Fuchsberg L. Ctr., J.D. Curriculum, Course Description, Foreign and International Legal Research, http://www.tourolaw.edu/Academics/ coursedetails.aspx?id=623 (accessed May 8, 2011); U. of Pac. McGeorge Sch. of L., Academic Programs, Course Descriptions, International and Foreign Legal Research, http://www.mcgeorge.edu/ x2460.xml?608 (accessed May 8, 2011); U. of Wash. Sch. of L., Course Catalog, International and Foreign Law Research, http://www.law.washington.edu/ Course Catalog/Course.aspx?ID=E579 (accessed May 8, 2011).

69. Brooklyn L. Sch., Curriculum, International and Foreign Law Research, http:// www.brooklaw.edu/academics/curriculum/coursedescriptions/course.aspx?id=L_087 (accessed May 8, 2011).

70. Villanova University School of Law, Syracuse University College of Law, and Brooklyn Law School have led the way in introducing courses that include an international moot court alternative to the traditional first-year legal writing curriculum. Edelman, It Began, supra n. 6, at 417.

71. Id.

72. Scholars addressing the challenges of teaching international LL.M. students particularly emphasize the need to directly examine differences of cultural context between the United States legal system and those of the students' home jurisdictions. E.g. Teresa Kissane Brostoff, Using Culture in the Classroom: Enhancing Learning for International Law Students, 14 Mich. St. J. Intl. L. 557, 560-564 (2007); Julie M. Spanbauer, Lost in Translation in the Law School Classroom: Assessing Required Coursework in LL.M. Programs for International Students, 35 Intl. J. Leg. Info. 396, 413-415, 421-431 (2007). 
observed that English is increasingly the language of choice for transnational negotiations and legal instruments, even in circumstances where the underlying transactions do not involve AngloAmerican law. ${ }^{73}$ Consequently, they also emphasize a transnational approach that responds to the needs of their students. These elective approaches respond to variance in student readiness and interest in global legal issues. More importantly, they probably reflect some combination of limitation in institutional resources, tentative institutional commitment, and/or a desire for experimentation.

While these experiments with globalization of LRW are salutary developments, we do not believe that they fully respond to the logic of the case for globalizing LRW. That argument, after all, posits that most (perhaps all) future lawyers will need global legal skills, not just a self-selected subgroup. ${ }^{74}$ If this premise is correct, only an approach that incorporates foreign and international research and reasoning into the standard LRW program for all students will truly suffice. It may be that we should also offer specialized, elective opportunities for more in-depth transnational training, but such courses are not a substitute for across-theboard instruction in transnational LRW skills.

We do not wish, however, to push the case for globalizing LRW too far. There are some important constraints on what can be done. In particular, any changes should guard against the risk of either displacing existing LRW pedagogy, or of overloading the LRW course with too many aims and objectives. ${ }^{75}$ With regard to displacement, we think the case for globalizing LRW is essentially additive. It does not diminish the importance of domestic law, nor does it claim any significant reduction in the role that domestic law will play in the law practice of the future. As a consequence, students will still need all of the present domestic LRW instruc-

73. Carole Silver, Internationalizing U.S. Legal Education: A Report on the Education of Transnational Lawyers, 14 Cardozo J. Intl. \& Comp. L. 143, 156-158 (2006).

74. See generally Arthurs, supra n. 1; see also Backer, supra n. 1, at 53-54; Chodosh, supra n. 1, at 847-849; Edelman, It Began, supra n. 6, at 415-416; Rumsey, supra n. 6, at 134.

75. Mirow notes that many doctrinal professors are apt to believe "that there is just no more room for expansion of [their courses] given limited hours of instruction." Mirow, supra n. 1, at 187. Susan Thrower suggests that there may be a balance between teaching theory and writing skills in those classes with a main emphasis on doctrine. Susan E. Thrower, Teaching Legal Writing through Subject-Matter Specialties: A Reconception of Writing Across the Curriculum, 13 Leg. Writing 3 (2007). 
tion they now receive, along with the addition of a global component. That component must be structured in such a way that it does not displace or undermine any of the existing important domestic objectives of LRW teaching.

The desire to avoid displacement in turn generates an attendant risk of overload. LRW is already a packed course with a full plate of important pedagogical objectives. Adding too much of a global component could overburden the course, making it too extensive for effective instruction. There is also a risk of overburdening legal writing professors who will have to develop at least basic expertise in the international and foreign legal systems and methods of research involved in such additional components. Some balance needs to be struck between preserving the legitimate domestic components of LRW and introducing the new material that is required to support a global component.

Accordingly, we envision a relatively modest adjustment in the traditional LRW course, not a total transformation. To refer to the matrix of globalization proposals we sketched above, ${ }^{76}$ we thus believe that LRW instructors should seek ways to introduce students to a global legal framework in the course of addressing a domestic legal problem, in a fashion that is mandatory rather than elective, integrated rather than supplemental, and that reflects "thin" exposure to rather than "thick" immersion in foreign and/or international law. It should be mandatory rather than elective in order to reach all students and to reflect the prospective ubiquity of globalization in American law. It should be integrated in order to reinforce the interconnectedness of transnational and domestic legal issues and client needs. And it should be thin in order to minimize the twin concerns of displacing or overloading existing LRW pedagogy.

There is clear appetite within the LRW community for ideas about how to incorporate international and comparative law. ${ }^{77}$ Several schools have had specialty tracks for some time where students self-select to be in international law-focused LRW sections. Brooklyn Law School and Villanova Law School epitomize

76. See supra text accompanying nn. 25-37.

77. A posting on the LRW listserv requesting information about courses that incorporate international or comparative law issues elicited numerous requests that we share the information that we gathered. 
this approach. ${ }^{78}$ For over thirty years, Brooklyn Law School has enabled students to choose a spring semester LRW section that focuses on international law. ${ }^{79}$ The Brooklyn class uses public international law issues that are set in the International Court of Justice at The Hague. "Previous topics have included diplomatic asylum, acid rain, treatment of refugees, access to the sea, response to terrorism, and the meaning of statehood." 80 Diane Edelman describes the comparable Villanova program in detail. ${ }^{81}$ As with the Brooklyn course, students opt in to this specialized LRW section that focuses on a problem set in the International Court of Justice. ${ }^{82}$

Several other schools also offer LRW sections with an international law focus. Kristen Martin of Whittier Law School teaches an international law section that is intended to support the school's Center for International and Comparative Law. ${ }^{83}$ Tom Cobb at the University of Washington School of Law has taught an asylum law elective practicum within the first-year LRW program that encompasses research on international human rights norms and laws of other countries. ${ }^{84}$ Syracuse University College of Law has two LRW sections with an international law focus. ${ }^{85}$ The students work on an international human rights issue in addition to a traditional domestic brief problem during the spring semester. ${ }^{86}$

Relatively few LRW programs to date have incorporated international or comparative law into the generic LRW curriculum. Teresa Brostoff and Ann Sinsheimer of the University of Pittsburgh School of Law have been trailblazers in this effort. Brostoff

\footnotetext{
78. Edelman, It Began, supra n. 6, at 417.

79. Email from Marilyn Walter, to Susan DeJarnett (June 3, 2008) (on file with Authors).

80. Id.

81. Edelman, It Began, supra n. 6, at 429-436.

82. Id. at 419,429 .

83. Martin's LRW problem topics have included marriage fraud, importation of goods made with child labor, extended border searches, collateral consequences of plea bargaining, and emergency medical care for undocumented aliens. Email Kristen Martin to Susan DeJarnett (May 28, 2008) (on file with Authors).

84. Email from Thomas Cobb, to Susan DeJarnett (May 28, 2008) (on file with Authors).

85. Email from Ian Gallacher, to Susan DeJarnett (June 11, 2008) (on file with Authors).

86. Id. The Syracuse students choose to enroll in these sections, but the school is considering moving the international focus until the third required semester of LRW. Email from Ian Gallacher, to Susan DeJarnett (June 12, 2008) (on file with Authors).
} 
and Sinsheimer teach generic LRW sections, not specialized sections aimed at students who choose the option. ${ }^{87}$ Over the years they have developed several interesting LRW problems with an international/comparative flavor. Examples include a contract dispute arising from conflicts between the definition of organic and genetically modified food under European Union and United States law, and a claim for airline passengers with tuberculosis arising under World Health Organization regulations and the Montreal/Warsaw Convention. ${ }^{88}$ The Pittsburgh problems end with a negotiation rather than with an argument. Pacific McGeorge School of Law has the most extensive incorporation program to date. All students at Pacific McGeorge take two years of a legal writing and skills program called Global Lawyering Skills that introduces them to and requires them to use international and foreign sources as well as domestic sources in solving client problems. ${ }^{89}$

LRW professors may legitimately ask why foreign or international law should take priority over other legal issues that may also be neglected in the first year. ${ }^{90}$ For example, lawyers in practice often face issues arising under regulations but administrative law is rarely the focus in most LRW courses. We acknowledge that the design of an LRW course and of an effective problem always involves tough choices. ${ }^{91}$ No course can cover every possible area of law that could come up regularly in practice. International and comparative law, however, occupy a dis-

87. Email Ann Sinsheimer, to Susan DeJarnett (May 29, 2008) (on file with Authors).

88. Id.

89. Second-year students who are members of the law review staff may opt out of the second-year course. All other students participate for two years, and all students have exposure to international and foreign law sources and issues in the problems they work with in the Global Lawyering Skills program. Interview and email exchange with Professor Hether Macfarlane, Instructor, Global Lawyering Skills (on file with Authors).

90. The difficulty of adding international and comparative law to an already full course is not unique to LRW. See Jukier, supra n. 23, at 172-173 (noting concerns about time constraints as a theme of the AALS 2006 meeting devoted to integration of transnational perspectives into the 1L curriculum); Legomsky, supra n. 1, at 485-487 (cataloguing list of components that ideally should be included into each course, including statutory interpretation, understanding of the administrative process, role-playing, alternative dispute resolution, ethics, social policy, historical context, jurisprudence, and more).

91. The journal Perspectives includes a regular feature called Brutal Choices in Curricular Design "designed to explore the difficult curricular decisions that teachers of legal research and writing courses are often forced to make in light of the realities of limited budgets, time, personnel, and other resources." E.g. Brutal Choices in Curriculum Design, 19 Persps. 134 (2011). 
tinctive place in this pantheon of choice because they take the students outside the domestic legal environment. The general doctrinal first-year curriculum is intended to introduce students to the fundamentals of the United States common law legal system and its major components, including regulation. LRW generally focuses on the fundamentals of domestic law, and we expect our students to learn enough to be able to apply the skills to other domestic problems. For example, an LRW class may focus on a state law problem set in California, but the students should be able to transfer their experience with researching California law to research a problem arising under New Jersey law. Adding a comparative or international component differs from other subject-matter choices because it takes that skill of transferring law to a new and different level.

\section{GLOBALIZING AN LRW ASSIGNMENT}

\section{A. General Considerations}

As any legal educator in the LRW field knows, problem design lies at the core of the LRW professor's mission. Welldesigned LRW courses teach the skills of research, analysis, and writing through a problem method. An effective problem gives the students the opportunity to learn the essential skills of lawyering in a realistic setting. Incorporating a new aspect in problem design is a challenge but also a source of excitement. If, as our survey demonstrates, ordinary lawyers commonly confront the need to access law from other jurisdictions, then LRW courses should introduce students to the means of doing that necessary task. It need not purport to be exhaustive; indeed, the introduction is likely to be just that-an introduction. But our task as LRW teachers is in part a gate-keeping function. We introduce students to the task of finding the law. Doctrinal courses provide the law to the students. Both LRW and doctrinal courses teach them how to use it. We are convinced of the value of opening this door so that students begin to see international and comparative law as part of their context as lawyers, instead of viewing these sources as something literally alien and reserved only for experts. ${ }^{92}$

92. LRW scholars have raised similar questions about the litigation focus of the 
LRW is typically the only first-year class that has a direct focus on advocacy. The spring semester in the usual LRW course is devoted to persuasive writing and typically is capped with an oral argument exercise. ${ }^{93}$ One of our fundamental beliefs is that lawyers generally-not just constitutional advocates before the United States Supreme Court-need access to the scope of arguments available through a global approach. ${ }^{94}$ Consequently, we think the advocacy component of the traditional LRW course may be the best place to think about incorporating a global legal issue.

Expanding the LRW course to include international and comparative law is not only important but can be energizing for the LRW professor as well as the students. We are used to developing substantive expertise in unfamiliar legal issues. ${ }^{95}$ An effective LRW problem needs to challenge the students to think creatively about research, to use the available sources effectively, and to take on the role of counselor or advocate. ${ }^{96}$ Including the world broadens the possibilities for problem issues and enriches existing

standard LRW pedagogy and have called for inclusion of transactional problems, noting that many lawyers will focus on transactional law in practice. See e.g. Louis N. Schultze, Jr., Transactional Law in the Required Legal Writing Curriculum: An Empirical Study of the Forgotten Future Business Lawyer, 55 Clev. St. L. Rev. 59 (2007).

93. Three-semester programs such as the one at Mercer may not focus on advocacy until the third semester but the LRW course remains the students' first in-depth exposure to advocacy. In doctrinal classes, students learn about the end result of advocacy-the decision-but there is little focus on the lawyer's craft of persuasion in those classes.

94. See Baumgartner, supra n. 66. Baumgartner notes that "[p]erhaps the biggest story in the development of transnational litigation during the last two decades, however, remains the extent to which cross-border cases have grown to become a significant part of the litigation landscape in the United States and elsewhere." Id. at 799. "Practicing lawyers need to know enough about foreign law to be able to tell when to contact local counsel and to communicate effectively with them in order to find the most advantageous forum for their clients and to litigate effectively there." $I d$. at 802.

95. See Leimer, supra n. 42, at 289.

96. Numerous LRW scholars have emphasized the need to determine the skills students need to develop and to then design the problems as the means to teach those skills. See e.g. Lorraine Bannai et. al., Sailing through Designing Memo Assignments, 5 Leg. Writing 193 (1999); Grace Tonner \& Diana Pratt, Selecting and Designing Effective Legal Writing Problems, 3 Leg. Writing 163 (1997). Kristin Gerdy analyzes the need for LRW problems to move from well-defined to ill-defined so that students can experience the

realistic situations in which attorneys and other legal researchers may find themselves. Such problems help students complete the learning process because they enable [the students] to "experience the compelling challenges typically faced by professionals in their disciplines" and to address both enduring (issues that recur in practice) and emerging issues and problems - the kind that "are fraught with the complicating factors of real life."

Kristin B. Gerdy, Teacher, Coach, Cheerleader and Judge: Promoting Learning through Learner-Centered Assessment, 94 L. Lib. J. 59, 67 (2002) (citations omitted). 
problems by adding a new dimension. Since students will face these issues in practice, ${ }^{97}$ we need to introduce them to this world now.

Guidelines for development of international or comparative law problems are not dramatically different than the usual guidelines for good problem design. ${ }^{98}$ The professor must decide what skills the problem should teach and reverse engineer an interesting fact scenario that will require students to develop those skills. One of the skills should be some form of research that requires the students to find and use international or foreign sources. In addition, effective problems are realistic. Students need to model the roles they are learning to assume. ${ }^{99}$ The LRW problems are more effective learning devices when the students can imagine the problem occurring in reality. ${ }^{100}$ The instructor should also consider how difficult the students' task should be-should the problem work as a persuasion exercise, requiring it to have reasonably strong arguments on both sides? Is it just going to be a predictive memo, making the balance less critical? Finally, it should still include counteranalysis and it should be clear why someone would need to research and write about the issue. ${ }^{101}$

\section{B. The DeJarnatt Experiment}

At our institution, we are committed to teaching LRW through the process method. We teach through the problems and interact with the students throughout the research and writing process. This is the common approach in state of the art LRW programs nationally. With that commitment in mind, Professor DeJarnatt needed to determine how best to incorporate foreign or

97. See e.g. id. at 72 .

98. See Bannai, supra n. 96, at 108; Tonner, supra n. 96, at 108.

99. See Susan L. DeJarnatt, Law Talk: Speaking, Writing, and Entering the Discourse of Law, 40 Duq. L. Rev. 489, 509 (2002).

100. Invented jurisdictions and cutesy fake names detract from this endeavor.

101. Professor DeJarnatt was often unsatisfied with her first problem when it was too easy. She used to design initial problems so that the answer was completely obvious once the students found the binding authority. But those problems were actually less effective as learning tools than a problem with a clear test but not a clear outcome. Many of the students struggled unnecessarily with the obvious answer problem because it made little sense to them to write up an answer. In real life, one would simply take the case to the assigning partner and let her know the answer. Professor DeJarnatt has found that the most effective writing experience results when there is a reason to write-in cases where the analysis may be clear but it is complicated enough for the assigning partner to benefit from a written explanation. 
international law into her LRW course while maintaining the inprocess checkpoints that form a critical part of the existing course design. What follows is her first-person reflection on how that process worked over two course administrations in 2008-2009 and 2009-2010. ${ }^{102}$

I focused on the spring semester for two reasons. First, LRW faculty at our institution believe it is critical for students to become part of the basic discourse community first-to learn how to find and find meaning in domestic legal resources so that they can become versed in the ways United States lawyers analyze legal problems, find solutions, and convey their analysis in writing to others. Second, I have not been able to find a way to include additional tasks in the already very full fall semester. ${ }^{103}$

The spring semester offers more options, however. Two years ago, I began teaching the spring semester through two trial level briefs instead of one appellate brief. This allows me to give the students practice in learning persuasion before they are assessed on their skills through grading. It also allows me to use the live conference technique ${ }^{104}$ and to try to make further use of the oral argument as a means of learning substance. ${ }^{105}$

102. Although this Article is co-authored, only one of us, Professor DeJarnatt, teaches LRW. Accordingly, from this point forward, references to the development of the problem and its use in LRW instruction will be presented from her perspective, utilizing firstperson singular pronouns for the work that Professor DeJarnatt did in her course.

103. In the fall semester, students write two predictive office memos, both fully researched. I meet with each student after submission of the first memo and a full written critique of that effort. The students then revise the first memo and add a new section on a related issue requiring additional research. I critique the revised memo while the students are working on their final memo, on which their grade depends. I meet again with each student after I critique a draft of the Discussion section of the memo. Diane Edelman suggests several options for programs that employ closed universe assignments which involve only writing and no research. Edelman, It Began, supra n. 6, at 438. She suggests emphasizing the role international and foreign law play within the domestic system, offering examples including asking the student to consider the application of Federal Rule of Civil Procedure 44.1 to a foreign adoption, or to determine whether a foreign corporation can obtain a dismissal of a federal court action based on forum non conveniens. The closed universe model allows the professor to more finely calibrate the difficulty of the assignment and makes it easier to include these issues. For reasons discussed at length elsewhere, I think the value of integrating research and writing outweighs the advantage of professorial control. See Ellie Margolis \& Susan DeJarnatt, Moving Beyond Product to Process: Building a Better LRW Program, 46 Santa Clara L. Rev. 93, 109-116 (2005).

104. In these conferences, I do not read and comment on the paper in advance. Instead, I read the paper in the student's presence, much as a supervisor might do, and the student gets to see my immediate reaction, including moments of confusion and frustration with the text. It is helpful for the student to receive both kinds of critique from me. See Daniel L. Barnett, "Form Ever Follows Function": Using Technology to Improve Feedback on 
The final memo problem I designed presents the students with the challenge of predicting how the court will resolve a California dispute between two couples who used the same fertility clinic. Both underwent in vitro fertilization but, due to clinic negligence, the embryos of the first couple, the Garcias, were accidentally and mistakenly used in the IVF procedure of the second couple, the Cohens. As a result the Garcias have a genetic connection to the child Mrs. Cohen gave birth to and believed was genetically related to her. Mr. Cohen is sterile, so he never expected to have a genetic connection to the child. Instead, the Cohens had intended to use the wife's eggs fertilized by donor sperm.

California law does not provide any easy way to determine who the legal parents should be. The statutes do not explicitly resolve the claims and the case law primarily focuses on parentage disputes arising from marital breakups and surrogacy disputes. 106 The students make a prediction about who will be declared the legal parents in a memo assignment during the fall semester. In the spring semester, the students are assigned to represent the couple whom they predicted would lose when they wrote their fall memos.

To those who do not practice family law, it may seem surprising that there are many potential international aspects to such a fundamentally domestic legal subject. Yet when we first began this project and I asked every lawyer I met whether they ever confront international law issues, the family law specialists uniformly stressed that that need comes up frequently, ${ }^{107}$ particularly in the context of a divorced or separated spouse wanting to take

\footnotetext{
Student Writing in Law School, 42 Val. U. L. Rev. 755, 765-766 (2008); Mary Beth Beazley, Better Writing, Better Thinking: Using Legal Writing Pedagogy in the "Casebook" Classroom (Without Grading Papers), 10 Leg. Writing 23, 56 (2004).

105. See DeJarnatt, supra n. 99, at 506-522.

106. Cal. Fam. Code $\S \S 7600-7607$ (2011); K.M. v E.G., 117 P.3d 673 (Cal. 2005); Johnson v. Calvert, 851 P.2d 776 (Cal. 1993).

107. Indeed a recent article calls for inclusion of transnational law in doctrinal courses focused on reproductive rights. Martha F. Davis \& Bethany Withers, Reproductive Rights in the Legal Academy: A New Role for Transnational Law, 59 J. Leg. Educ. 35 (2009). Davis and Withers analyze how "a transnational perspective might enhance the teaching of sexual and reproductive health in all of the law school course and doctrinal settings in which this topic [is] treated." Id. at 37. The article, like the others noted earlier, omits LRW from its focus but does address bioethics, the right to benefits of scientific progress, and the right to receive information, which all relate to the ART issues at the heart of the IVF problem.
} 
a child on a trip outside of the United States. ${ }^{108}$ More recently, the Artificial Reproductive Technologies ("ART") subcommittee of the ABA Family Law section has been focused on several international issues involving the law relating to transnational use of ART techniques and international adoption. These issues require the domestic lawyers to access the various Hague Conventions relating to children. ${ }^{109}$ They also require the lawyers to access the domestic laws of the other countries related to a particular dispute. It was thus both logical and relatively easy to find a way to incorporate international and comparative law into my family law problem.

In past years, my first brief has focused on the putative genetic parents' demand for genetic testing to prove their claim. The second brief then focuses on parentage - the heart of the dispute. In 2009, I advanced the litigation so that genetic testing has already established the link between the child and the genetic parents, the Garcias, who have now been granted monthly visitation pending the final resolution of the case. Mrs. Garcia's mother lives in Guatemala, is seriously ill, and is unable to travel. The Garcias ask the court to order the Cohens to sign a passport application for the child so that he may travel with them to Guatemala to visit the grandmother during one of the monthly visits. The students must determine that, under California law, the court uses a factors test to decide whether the travel should be allowed. ${ }^{110}$ Several factors implicate international and foreign law. The court must evaluate the ties that the requesting parent has to the jurisdiction. The judge must also consider the risk of abduction. Implicit in this analysis is the ease or difficulty the

108. A recent high profile case involved a child named Sean Goldman whose mother took him on a vacation to Brazil, her home country, and then filed for divorce in Brazil. Sean's father battled in the Brazilian courts for years before finally regaining custody of his son. The battle raged on despite the father's rights under the Hague Convention and despite the death of Sean's mother. Kirk Semple \& Merry Galanterick, Boy, 9, and Father Are Back in U.S. after Reuniting in Brazil, N.Y. Times (Dec. 24, 2009) (available at http://www.nytimes.com/2009/12/25/world/americas/25brazil.html?_r=1\&scp=1\&sq=Brazil +Hague+Convention+Sean\&st=nyt).

109. For example, see Convention of 25 October 1980 on the Civil Aspects of International Child Abduction; Convention of 19 October 1996 on Jurisdiction, Applicable Law, Recognition, Enforcement and Co-operation in Respect of Parental Responsibility and Measures for the Protection of Children; Convention of 23 November 2007 on the International Recovery of Child Support and Other Forms of Family Maintenance (available at http://www.hcch.net/index_en.php?act=conventions.listing).

110. Cal. Fam. Code. Ann. § 3048 (West 2004). 
objecting parent may have in securing the return of an abducted child under the laws of the foreign jurisdiction. This issue also implicates the Hague Convention on child abduction. ${ }^{111}$ The students then need to find the Convention, determine the processes it provides for return of children, determine whether Guatemala is subject to the Convention, and research case law under the Convention to see how courts have handled claims of abduction.

This motion requesting that the Cohens sign the passport application does not primarily concern a matter of international law, but it proved to be a useful vehicle for introducing students to the concept of international conventions, the means for finding them, and the ways to determine whether the relevant Convention is in effect in the other country. The other area of research that proved fruitful to the students was the United States State Department website on Guatemala. Many students made very effective use of the information they found there regarding crime rates, especially for kidnapping, and warnings regarding local concerns about international adoptions of Guatemalan children, which they employed to argue that the proposed trip put the child at unacceptable risks of harm. It was a very useful exercise in persuasion.

The students' reaction to the problem was strongly positive. ${ }^{112}$ Their biggest frustration had nothing to do with the international aspects but with the dearth of reported California cases on the factor test for permitting international travel. Very few of the numerous relevant California decisions had been officially reported and, under California rules, those unpublished decisions cannot be cited in a brief. Although the students struggled with this limitation initially, many of them noted in their course evaluations that this situation was a blessing in disguise as it allowed them to place less reliance on precedent and focus more exclusively on persuasion. ${ }^{113}$

111. The Hague Convention on the Civil Aspects of International Child Abduction, Oct. 25, 1980, supra n. 109.

112. In student course evaluations, twenty-seven out of thirty respondents said they found the topic interesting. Twenty-six said they agreed that learning something about the skills of finding and using international law will be useful to them in their future work. Feedback Forms on Passport Motion (on file with Author).

113. Relevant comments included: "I liked the passport motion because without research, it allowed us to focus on the new format of the brief"; "I liked the passport [motion] because it forced us to get creative where case law didn't exist"; "I think the passport motion is more interesting. That is to say it focused specifically on our ability to write per- 
The second way I tried to incorporate foreign law was in the motion for summary judgment on parentage that was the final project for the year. I did not think I could ask the students to consider the parentage laws of the entire world given the limited amount of time they had to conduct their research. ${ }^{114}$ Instead I directed them to research Canadian law. I chose Canada because it is primarily a common law jurisdiction, ${ }^{115}$ has a statute governing artificial reproductive technology (ART), ${ }^{116}$ and has a variety of cases, all published in English. The style of writing in the cases, however, is quite different from what is typical in United States judicial writing. ${ }^{117}$ The most common dispute in Canada, moreover, was not a dispute between a surrogate and the intended parents but between the intended parents and a government functionary who refused to put the intended parents on the birth certificate in situations where the intended mother did not give birth. ${ }^{118}$

This experiment was less successful because it was too artificial. Few students were able to use Canadian law in any effective way, and they all recognized that in real life it would not be particularly persuasive to try. If Canada had law that directly dealt with an embryo mix-up, the experiment would have been more useful. Nevertheless, it was still helpful for the students to learn how to access the statutes and cases of another country and to see how the writing style varied.

In 2009-2010, I altered the problem to try to address at least some of the limitations I experienced the previous year. I taught in the evening division in 2009-2010, which posed even greater time constraints on the students and on the course. My main goal was to make the need to examine Canadian law more realistic. Instead of the motion to compel a passport, I asked the students to write a strategy memo. In this version of the problem, just after the genetic testing is performed and the court grants tempo-

\footnotetext{
suasively with little research to rely on." Id.

114. The students had only a few weeks to complete the research for this project.

115. See Jukier, supra n. 23, at 175.

116. Assisted Human Reproduction Act, SC. 2004, c. 2.

117. The Canadian opinions tend to be much more narrative than United States opinions. The sources relied on are listed at the outset. See e.g. A.(A.) v. B.(B.), [2007] 83 O.R. (3d) 561.

118. See e.g. Rypkema v. Brit. Colum., [2002] B.C.J. No. 272, 2003 BC.C. LEXIS 4820; J.R. v. L.H. [2002] O.J. No. 3998, 2002 ON.C. LEXIS 799 (O.S.C.J. Sept. 3, 2002).
} 
rary custody to the Cohens and visitation to the Garcias, the students learn that the Cohens are going to move to Toronto so that Mr. Cohen, a television writer and director, can work on a television show that is being produced there. The move will be relatively long-term but not permanent. I asked the students to determine whether the move makes Canadian law controlling and to evaluate the arguments their clients could make or use to rebut under Canadian law. The decision to assign a strategy memo, rather than a full blown brief, 119 more realistically justified why the students should analyze Canadian law but still led them to look at both the Convention on child abduction and the Uniform Child Custody Jurisdiction and Enforcement Act. ${ }^{120}$ It also gave them some experience in a different style of writing than either the formal office memo of the first semester or the full blown brief they do later in the spring.

Incorporating international and foreign law does involve another layer of decision making in problem design. Should the students' experience be limited to common law jurisdictions? Should they have to deal with translation? Should the focus be on international or comparative law or both? How much depth can or should be required? My approach was to construct an occasion for a limited foray into the law of a sister common-law jurisdiction that conducts business in English and shares substantial jurisprudential common ground with the United States. Choosing a civil-law jurisdiction with a divergent legal structure and a different language would have added considerably to the challenge of even such a relatively simple problem.

119. I had the students submit this memo by email to give them some experience in a different style and format of writing. While I remain committed to using the formal office memo as a useful means to teach students how to convey analysis, I recognize that the use of formal office memos has declined in practice as technology has allowed less formal means of communication. See Kristen Konrad Robbins-Tiscione, From Snail Mail to Email: The Traditional Legal Memorandum in the Twenty-First Century, 58 J. Leg. Educ. 32 (2008); see also Maria Perez Crist, Technology in the LRW Curriculum-High Tech, Low Tech, or No Tech, 5 Leg. Writing 93, 101-103 (1999) (arguing for greater use of email within the LRW curriculum because of the growing use of email in law practice).

120. Cal. Fam. Code $\S \S 3400-3406$. The UCCJEA provides the California structure for determining jurisdiction in cross-border custody cases, including those that involve international borders. 


\section{TOPICS FOR GLOBAL LRW PROBLEM DEVELOPMENT}

However far one strays from familiar legal terrain, we advocate the use of problems that emulate what our survey respondents relayed to us about the types of foreign or international legal issues they typically encounter. Using the kinds of issues that ordinary lawyers face will drive home the reality that these skills are going to be useful to the students in their practice lives and will give them experience in situations that may actually arise when they enter practice. What follows are a few selected examples of promising scenarios that arise out of the actual problems our survey respondents described. The list of topics in Appendix F should suggest additional ideas for potential LRW problem development.

\section{A. Family Law}

One issue that was frequently identified by family law practitioners was child custody and visitation involving international travel. Effective LRW problems can be developed that focus on various aspects of the Hague Convention on the Civil Aspects of International Child Abduction. ${ }^{121}$ The Abduction Convention must be considered when a parent in a custody dispute fears that the contesting parent may leave the country or when the contesting parent has left the country and is not returning the child. The Convention allows multiple levels of complexity. An introductory problem could focus on fact disputes that determine how to define "habitual residence." 122 State law allowing issuance of a ne exeat order under particular circumstances could also provide a basis for a good problem-for example, whether in the course of a contested divorce, one parent should be allowed to take the children with her to another country where the parent has a temporary work posting like a sabbatical or visitorship. Students would need to argue whether the proposed trip precludes adequate contact with the remaining parent, whether there is any risk of ab-

121. Hague Convention on Civil Aspects of International Child Abduction, supra n. 109; 42 U.S.C. \$ 11601 (2006) (implementing statute).

122. Mozes v. Mozes, 239 F.3d 1067 (9th Cir. 2001) (determining habitual residence under the Hague Convention where mother, with consent of father, had moved temporarily to the United States from Israel but, after living in the United States for a year, then filed for divorce and custody). 
duction, and whether the child's presence in the other country presents any risks. Beyond child custody, other legal issues with potential international or comparative components concern the legal status of marriage or divorce, or the enforceability of domestic relations orders by foreign tribunals.

\section{B. Commercial Law}

"Fertility tourism" is the somewhat derisive term for crossborder travel to access artificial reproductive services that are restricted or unavailable in the traveler's home country. ${ }^{123}$ Such tourism can be a two-way street. ${ }^{124}$ Canada, for example, imposes severe penalties on anyone who provides compensation to a gestational surrogate. ${ }^{125}$ The risk of a serious fine and even jail time acts as a deterrent to Canadians who have no access to altruistic surrogates within Canada. ${ }^{126}$ The restrictions encourage Canadians to access ART services in the United States or other countries. ${ }^{127}$ On the other hand, Canada can be an attractive destination for intending parents who are not Canadian but who have access to an altruistic Canadian surrogate because the public health system greatly reduces the medical costs for the pregnancy and birth of the baby. ${ }^{128}$ India has a growing reputation for providing low-cost gestational surrogacy as it allows women to be compensated for providing such services. ${ }^{129}$ All of these scenarios

123. See Jennifer Rimm, Student Author, Booming Baby Business: Regulating Commercial Surrogacy in India, 30 U. Pa. J. Intl. L. 1429 (2009).

124. Lise Ikemoto provides a very useful overview of the current state of the fluid and growing international market for fertility and reproductive medical services. See Lise C. Ikemoto, Reproductive Tourism: Equality Concerns in the Global Market for Fertility Services, 27 L. \& Inequal. 277 (2009).

125. See Assisted Human Reproduction Act, S.C. 2004, c. 2, s. 6. (prohibiting payment of consideration to a surrogate mother); SC c. 2, s. 60 (providing for fines of up to $\$ 500,000$ and imprisonment for up to ten years for those convicted of violating section 6).

126. See Rakhi Ruparelia, Giving Away the "Gift of Life": Surrogacy and the Canadian Assisted Human Reproduction Act, 23 Can. J. Fam. L. 11 (2007).

127. See Judith Daar, Presentation, Accessing Reproductive Technologies: The Role of Fertility Tourism (Montreal, Can. Oct. 9, 2009) (materials on file with Authors) (discussing how varying restrictions, regulation, and pricing of ART services in different countries has led to cross-border travel to access services and to reduce costs).

128. Ailis L. Burpee, Note, Momma Drama: A Study of How Canada's National Regulation of Surrogacy Compares to Australia's Independent State Regulation of Surrogacy, 37 Ga. J. Intl. \& Comp. L. 305, 328 (2009).

129. See Ikemoto, supra n. 124, at 277-278 (arguing that media portrayals have "fetishized" India as a destination for fertility tourism and have paid insufficient attention to other destinations); see also Rimm, supra n. 124 (examining India's market for fertility 
present potential LRW problems addressing contract interpretation and enforceability. Students can determine the enforceability of a contract to be performed in India, created in the U.S. by a U.S. fertility agency and Canadian intended parents.

Another useful foundation for a contract-oriented LRW problem is the United Nations Convention on Contracts for the International Sale of Goods ("CISG"). 130 The United States is a signatory to the CISG which is intended to provide a structure for international contract similar to that offered by the Commercial Code and UCC case law is relevant to interpretation of CISG cases. ${ }^{131}$ Foreign case law is also considered instructive though not binding, ${ }^{132}$ allowing an LRW problem to easily incorporate an international convention, foreign law, and domestic law in one fact scenario. ${ }^{133}$

\section{Procedural Issues}

LRW problems typically focus on a disputed area of law or at least a factual dispute. However, it could be worthwhile to build a memo problem that would require students to determine the requirements to properly serve process on a foreign defendant. Students need to develop familiarity with domestic rules of procedure as well as international requirements. ${ }^{134}$ For instance, a

tourism in detail).

130. U.N. Convention on Contracts for the International Sale of Goods (CISG), Apr. 11, 1980, S. Treaty Doc. No. 98-9 (1983), 1489 U.N.T.S.3; see Michael Joachim Bonell, The CISG, European Contract Law and the Development of a World Contract Law, 56 Am. J. Comp. L. 1 (2008) (tracing the role of the CISG as a "veritable world sales law"); Ingeborg Schwenzer \& Pascal Hachem, The CISG-Successes and Pitfalls, 57 Am. J. Comp. L. 457 (2009) (providing helpful explanation of the history and role of the CISG in international trade);.

131. See Chi. Prime Packers, Inc. v. Northam Food Trading Co., 408 F.3d 894, 898 (7th Cir. 2005) (describing the CISG as "the international analogue to Article 2 of the Uniform Commercial Code").

132. CISG Art. 7; Schwenzer \& Hachem, supra n. 130, at 468.

133. An expansive ALR annotation provides a nice list of cases from which a scenario could be derived. Elizabeth D. Lauzon, Construction and Application of United Nations Convention on Contracts for the International Sale of Goods (CISG), 200 A.L.R. Fed. 541 (2005).

134. Baumgartner notes that transnational litigators need familiarity with foreign as well as domestic procedure. Baumgartner supra n. 66, at 795 ("Most of the action in transnational litigation in recent years has been in the areas of personal jurisdiction, foreign sovereign immunity, the Alien [Tort Statute], forum selection clauses, and forum non conveniens, tightly followed by the recognition of foreign judgments, and a bit further behind, transnational discovery and the action of state doctrine ...."). 
problem could be created using the real-life scenario faced by one of the survey respondents. The reported lawsuit was brought in the United States District Court. ${ }^{135}$ It involved the personal injury action of a woman who sued a hotel in Cairo that is part of an international chain, alleging the hotel was liable for the hotel employee who directed the woman to take a camel ride that was not hotel sponsored, and that resulted in her injury. This scenario would no doubt raise questions about jurisdiction over the Egyptian subsidiary. A more basic problem could require the students to determine the governing rules for service of process on the foreign entity that operated the camel ride. The students would need to research the Federal Rules of Civil Procedure and the Hague Convention on the Service Abroad of Judicial and Extrajudicial Documents in Civil or Commercial Matters. ${ }^{136}$

Human rights cases provide an array of interesting procedural issues, including questions of personal jurisdiction. ${ }^{137}$ Several important cases brought under the Alien Tort Statute (ATS) ${ }^{138}$ could form the basis for interesting LRW problems involving cor-

135. Survey answer 101.

136. Convention of 15 November 1965 on the Service Abroad of Judicial and Extrajudicial Documents in Civil or Commercial Matters (available at http://www.hcch.net/index _en.php?act=conventions.text\&cid=17).

137. Beth Stephens, Translating Filartiga: A Comparative and International Law Analysis of Domestic Remedies for International Human Rights Violations, 27 Yale. J. Intl. L. 1 (2002) (examining the procedural advantages to Alien Tort Statute suits against corporations within domestic courts); see Student Author, Civil Procedure-Pleading Requirements-Eleventh Circuit Dismisses Alien Tort Statute Claims against Coca-Cola under Iqbal's Plausibility Pleading Standard, 123 Harv. L. Rev. 580 (2009) (discussing dismissal of Sinaltrainal v. Coca-Cola, 578 F.3d 1252 (11th Cir. 2009)); Christopher A. Whytock, Domestic Courts and Global Governance, 84 Tul. L. Rev. 67, 70 (2009) (asserting that domestic courts perform a "global governance function" in resolving transnational human rights cases).

138. The Alien Tort Statute, 28 U.S.C. $§ 1350$ provides that " $[\mathrm{t}]$ he district courts shall have original jurisdiction of any civil action by an alien for a tort only, committed in violation of the law of nations or a treaty of the United States." The Torture Victims Protection Act, also codified at 28 U.S.C. $§ 1350$, further provides for federal jurisdiction over claims of torture and murder committed under color of law. Efforts to bring ATS/TVPA claims in the U.S. against multinational corporations for actions of non-United States subsidiaries have raised challenging questions of personal jurisdiction, venue, and forum non conveniens. See e.g. Wiwa v. Royal Dutch Petroleum Co., 226 F.3d 88 (2d Cir. 2000) ( holding that personal jurisdiction was properly exercised over holding companies incorporated in England and the Netherlands based on the companies' maintenance of an Investor Relations Office in New York). The lawsuit sought compensation for the defendants' alleged complicity in human rights abuses committed in Nigeria by the Nigerian government at the instigation of the defendants' Nigerian subsidiary. Id. at 92. The Second Circuit also reversed the lower court's forum non conveniens dismissal, holding that the TVPA strongly supports the exercise of jurisdiction in the United States. $I d$. 
porate structures and personal jurisdiction or other procedural issues. The Torture Victims Protection Act (TVPA) directs a court to refuse to exercise jurisdiction if the plaintiff has failed to exhaust "adequate and available remedies in the place in which the conduct giving rise to the claim occurred." 139 A problem could raise this issue by including facts that could show remedies to be available in the foreign country. A recent case presents the interesting twist of a change of government in Bolivia. ${ }^{140}$ The new government provided compensation to the victims of the Bolivian Gas War and the court dismissed the TVPA suit, holding that the compensation satisfied the adequate remedies requirement. ${ }^{141}$ The problem could focus on availability, adequacy, or both. ${ }^{142}$ ATS and TVPA cases provide ways to get the students to focus on bread and butter process issues but in factual contexts they may find compelling. ${ }^{143}$

\section{CONCLUSION}

As matters presently stand in most American law schools, it is quite possible to obtain a J.D. without ever having taken an international law course or without having considered how other countries might approach or solve a legal problem. In most jurisdictions, it is quite possible to be admitted to the bar without knowing anything at all about law outside the United States. But at this juncture it is much less possible to practice law without confronting some issue arising from international or foreign law. Law students will be better prepared for practice if they can begin to consider international and foreign law in their learning process

139. 28 U.S.C. $\S 1350$ (2)(b) (2006).

140. Rojas Mamani v. Sanchez Berzain, 636 F. Supp. 2d 1326 (S.D. Fla. 2009).

141. The TVPA claims were dismissed without prejudice and the court subsequently denied in part the defendants' motion to dismiss the remaining ATS and state law claims. See Order, Rojas Mamani v. Sanchez Berzain, No. 07-22459-CIV-JORDAN \& No. 0821063-CIV-JORDAN, slip op. at 40 (S.D. Fla. Nov. 9, 2009).

142. Defendants seeking dismissal on this basis have often lost because they failed to meet their burden of persuading the court that the existing remedies met the adequate and available standard. See e.g. Sinaltrainal v. Coca-Cola Co., 256 F. Supp. 2d 1345 (S.D. Fla. 2003). In Enahoro v. Abubakar, 408 F.3d 877 (7th Cir. 2005), the court remanded so the district court could determine whether to allow plaintiffs to amend to state a TVPA claim and to determine whether the exhaustion requirement was met.

143. The main downside to these problems is that they do not lend themselves easily to become the basis for persuasive problems in the advocacy semester. Many students are going to be uncomfortable defending the person accused of torture and other serious human rights abuses. 
early in the academic experience. Today's lawyers will need to engage the world. They should begin that engagement in law school. Leaving international and foreign law solely to specialized experts contributes to the outdated notion that such law is not part of the ordinary lawyer's world. Opening the door to the world of international and foreign law in the context of first-year legal research and writing will help our students recognize and prepare to work effectively in the global legal practice that awaits them. 


\section{APPENDIX A}

Survey of international and comparative law experiences in practice

I. Practice experience

1. How long have you been in the active practice of law, including any judicial clerkship experience?

_ Fewer than 5 years

- 5-10 years

- 11-20 years

— More than 20 years

2.Please list the year you graduated from law school

3. Do you practice in

Private law firm of 1-10 lawyers

_ Private law firm of 11-50 lawyers

_ Private law firm of 51-100 lawyers

_ Private law firm of over 100 lawyers

Civil government

Civil public interest

Prosecutor's office

_ Public Defender

Corporate in house

Other (Please describe)

4. Please describe the focus of your practice-e.g. general litigation, corporate and commercial, patent, family law, criminal defense, etc.

5. Client base: Do you draw the bulk of your clients from the Philadelphia area Regionally (Pennsylvania, New Jersey, Delaware)

Nationally

Internationally 
II. Experience with international and comparative law problems

1. Have you ever worked on an international legal matter, including any that required consultation with local foreign counsel, that required you to know something about:

foreign law (that is, the law of another country)

international law (e.g., UN Conventions, WTO

decisions, treaties signed by the United States)

both

neither

2.If yes, how often has this occurred within the last year? Please answer based on the number of separate projects, not the number of cases or clients.

- 1-5 times

- 6-10 times

More than 10 times

3. Within the last 5 years:

$\begin{array}{ll}\square & \text { None } \\ & 1-5 \text { times } \\ & 6-10 \text { times } \\ & \text { More than } 10 \text { times }\end{array}$

4. Over 5 years ago:

None

- 1-5 times

- 6-10 times

_ More than 10 times

5. We are also interested in finding out how often the foreign or international law was necessary to resolve a domestic law question in contrast to how often the international or foreign legal question was relevant by itself. For example, a lawyer might research how other countries have treated surrogacy contracts to illuminate arguments about the validity of such contracts in Pennsylvania. In contrast, a lawyer might need to learn about the family law of another country to determine the marital status for purposes of United States law of an immigrant from that country. In thinking about the projects you listed in Section II, please estimate what percentage of 
the time knowledge of international or foreign law was necessary to resolve a domestic law question.

6. If you feel comfortable doing so, please describe briefly the nature of the problem and the research required for one or more representative situation(s) you faced: 
APPENDIX B

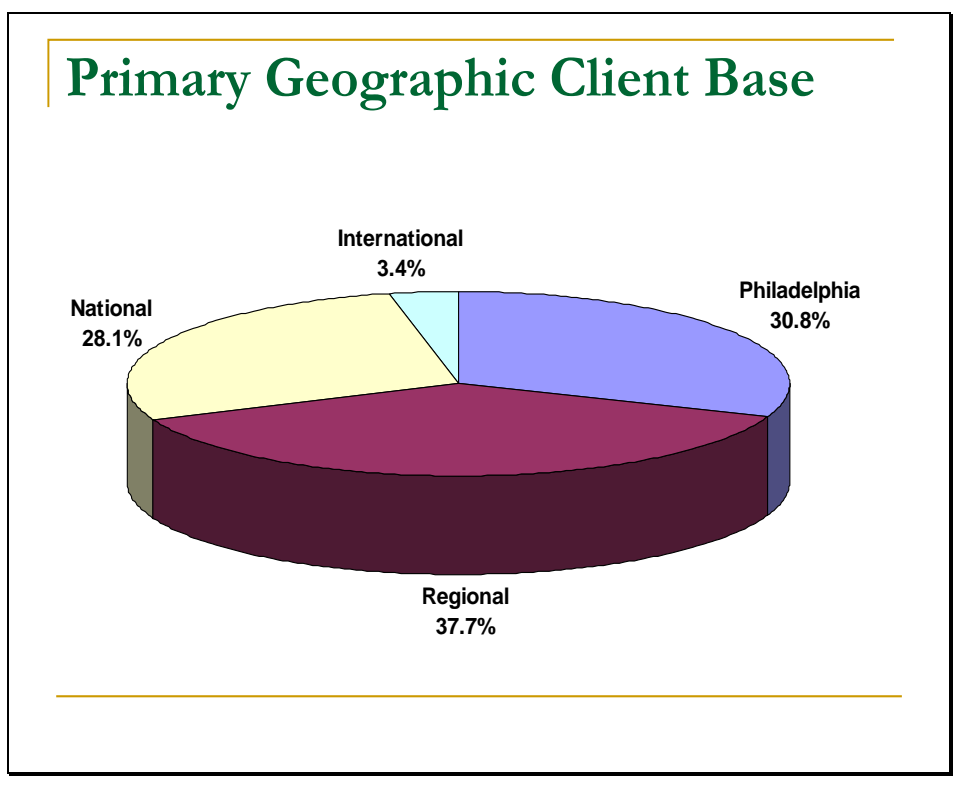

APPENDIX C

Have you ever worked on a legal matter that required you to know something about:

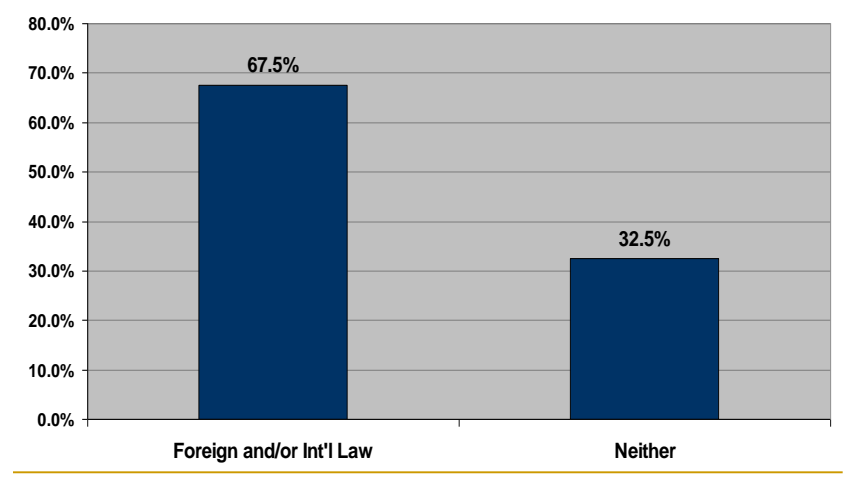


APPENDIX D

\section{Positive Responses}

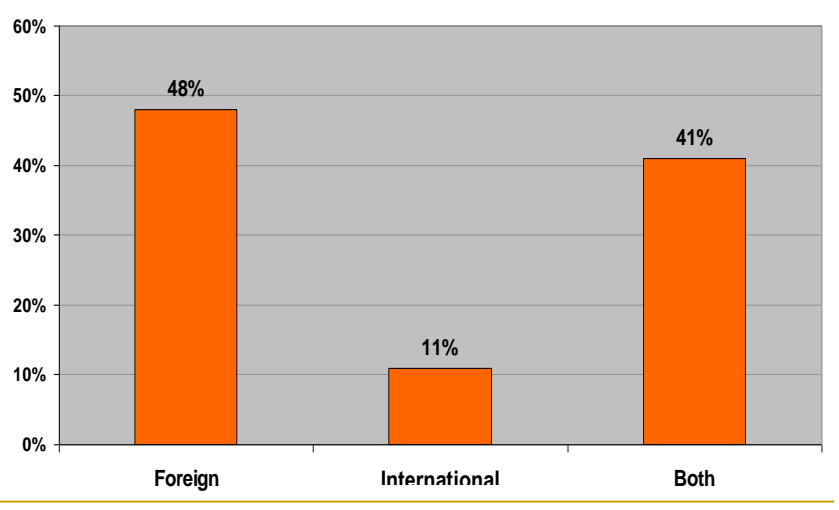


APPENDIX E

How many times did the need arise within the last year?

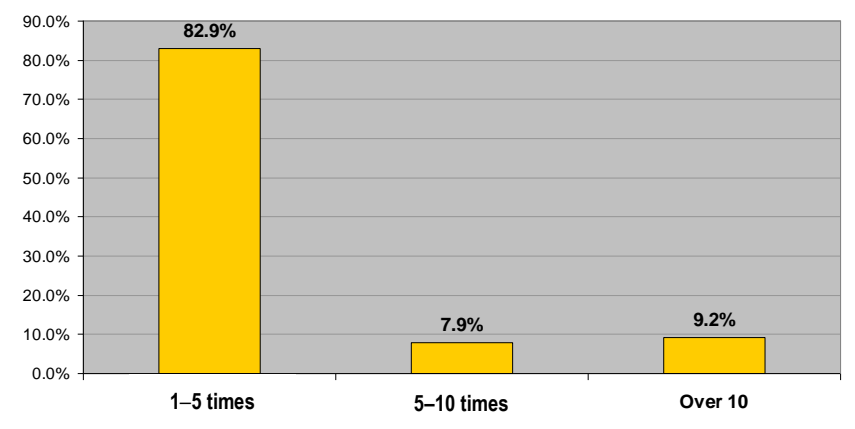

How many times did the need arise within the last 5 years?

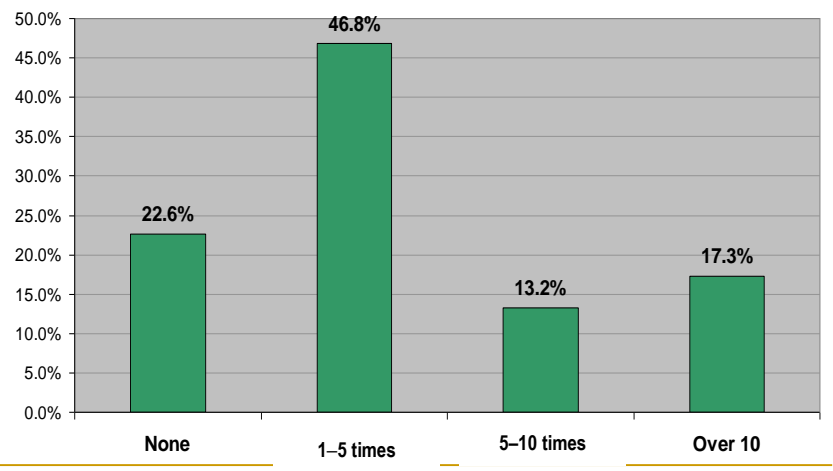


How many times did the need arise over 5 years ago?

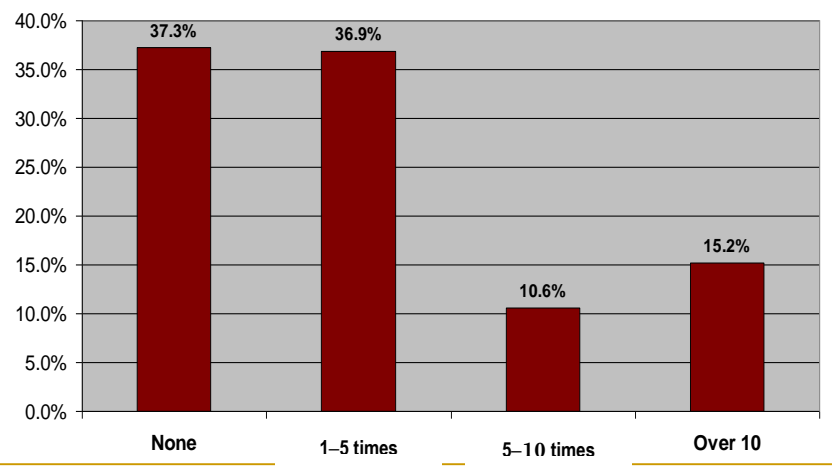




\section{APPENDIX F $F^{144}$}

\begin{tabular}{|c|c|c|}
\hline Area of law & & Type of issue \\
\hline Bankruptcy & & $\begin{array}{l}\text { Whether defendant's filing for bankruptcy in Italy affected } \\
\text { a lawsuitpending in U.S. District Court. } \\
\text { Whether companies in Luxembourg and the Netherlands } \\
\text { must liquidate or can reorganize. } \\
\text { Comparison of U.S. and German insolvency laws to avoid } \\
\text { transfers to German-affiliated companies. } \\
\text { Consideration of creditors' rights issues involving cross- } \\
\text { border insolvency proceedings in Canada. } \\
\text { Research of Hong Kong and Chinese liquidation proce- } \\
\text { dures to deal with contract dispute with a Hong Kong } \\
\text { company which wasin liquidation. }\end{array}$ \\
\hline Commercial law & 1. & $\begin{array}{l}\text { Consideration of corporate transactions under Islamic } \\
\text { law. } \\
\text { Research related to construction of international airportin } \\
\text { Africa. } \\
\text { Representation involving American company with foreign } \\
\text { affiliates in countries that enacted 'blocking statutes" in } \\
\text { response to U.S. embargo against trade with Cuba. } \\
\text { Needed to obtain opinions of foreign counsel to non-U.S. } \\
\text { banks that were guaranteeing obligations of their U.S.- } \\
\text { based subsidiaries. } \\
\text { Needed to research foreign law to determine whether cli- } \\
\text { ent could terminate a long-term contract entered into in } \\
\text { U.S. but to be performed in a foreign country whose law } \\
\text { placed substantial limitations on client's ability to unilat- } \\
\text { erally terminate the contract. } \\
\text { Represented a Canadian citizen dealing with Canada's } \\
\text { blocking statute that criminalizes compliance with U.S. } \\
\text { trade embargo on Cuba. } \\
\text { Client was considering acquiring a business in Germany } \\
\text { but decided not to after realizing the reach of pro-employee } \\
\text { laws there. } \\
\text { Research related to the ability of Swiss non-profit corpora- } \\
\text { tion to provide seal of approval for products and analysis of } \\
\text { liability issues associated with such approvals. } \\
\text { Whether foreign law would help a business do something } \\
\text { that U.S.law constrained or prohibited. } \\
\text { Research on choice of law clause in carriage of cargo af- }\end{array}$ \\
\hline
\end{tabular}

144. All responses provided in Survey Answers on file with Authors. 


\begin{tabular}{|c|c|c|}
\hline & & $\begin{array}{l}\text { fected by foreign law. } \\
\text { Research on foreign law relevant to commencial lender's } \\
\text { operations in Latin America. } \\
\text { Research on U.K. law relevant to investment manage- } \\
\text { mentclients. }\end{array}$ \\
\hline Corporate law & $\begin{array}{l}6 . \\
7 . \\
8 . \\
9 . \\
10 .\end{array}$ & $\begin{array}{l}\text { Research on the requirements of Toronto stock exchange } \\
\text { and Canadian corporate law. } \\
\text { Whether client's manufacturing company needed to com- } \\
\text { ply with regulations governing its European operations. } \\
\text { Creation of joint venture agreements with foreign compa- } \\
\text { nies or in foreign countries. Completion of property acqui- } \\
\text { sition in foreign countries. } \\
\text { Whether a foreign entity was the legal successor to anoth- } \\
\text { er foreign entity that owned } 100 \text { percent of the shares of a } \\
\text { U.S. corporation; resolved by reviewing presidential de-- } \\
\text { crees of the foreign country. } \\
\text { Creation of contracts in under-developed countries where } \\
\text { corruption is a major problem; avoiding corruption by } \\
\text { avoiding the legal system through contract drafting that } \\
\text { allows resolution of disagreements in a neutral country } \\
\text { under contract principles. } \\
\text { Whether a company engaged in a transaction is subject to } \\
\text { notification provisions of foreign competition authorities. } \\
\text { Whether facets of foreign entity formation law affect com- } \\
\text { petition filings either abroad or in U.S. } \\
\text { Drafting of joint agreements under foreign law affecting } \\
\text { mining of valuable stones. } \\
\text { Whether regulations imposed by foreign jurisdictions af- } \\
\text { fect client's foreign investments or foreign shareholders. } \\
\text { Research on how to comply with regulations as client's } \\
\text { subsidiaries entered highly regulated foreign businesses, } \\
\text { e.g. banking in Ireland. } \\
\text { Whether companies engaged in joint venture with U.S. } \\
\text { company were properly organized under Ukrainian law } \\
\text { and whether contracts were enforceable under Ukrainian } \\
\text { law. } \\
\text { Served as general counsel to U.S. subsidiary of U.K. com- } \\
\text { pany. } \\
\text { Handled corporate governance and mergers and acquisi- } \\
\text { tionsissues in China. }\end{array}$ \\
\hline
\end{tabular}




\begin{tabular}{|c|c|c|}
\hline Criminal law & $\begin{array}{l}3 . \\
4 .\end{array}$ & $\begin{array}{l}\text { Research related to fighting extradition to India on charg- } \\
\text { es of embezzlement and corporate malfeasance. } \\
\text { Research for an amicus brief on sentencing juveniles to life } \\
\text { without parole and onjuvenile strip searches. } \\
\text { Researched extradition laws of Canada and Mexico. } \\
\text { Drafting of mutual legal assistance treaty for prosecution } \\
\text { of drug dealers. } \\
\text { Research on laws of defendant's country of origin to ne- } \\
\text { gate mens rea. } \\
\text { Research of laws of countries involved in FBI investiga- } \\
\text { tion of movement of gold across borders. } \\
\text { Deposition of Italian witness in federal criminal trial; tes- } \\
\text { timony taken in Italy. } \\
\text { Research on international treaties dealing with apartheid } \\
\text { era in South Africa related to federal criminal prosecution. } \\
\text { Research on the right of foreign nationals to carry fire- } \\
\text { arms in the U.S. } \\
\text { Research on arrest status and consul notification re- } \\
\text { quirements for foreign nationals. } \\
\text { Research on release from criminal detention in foreign } \\
\text { country and availability of prisoner transfer treaty be- } \\
\text { tween that country and the U.S. } \\
\text { Research and representation relating to major white col- } \\
\text { lar criminal investigation involving international matters. } \\
\text { Whether an adjudicated violation of the International } \\
\text { Covenant on Civil and Political Rights is a bar to the exe- } \\
\text { cution of a death row inmate. } \\
\text { Research on the effect of practices of other nations on } \\
\text { "evolving standards of decency" in } 8^{\text {th }} \text { Amendment argu- } \\
\text { ment against executions of the mentally disabled and ju- } \\
\text { veniles. }\end{array}$ \\
\hline Employment & 2. & $\begin{array}{l}\text { Research on non-compete issues under English law in an } \\
\text { action pending in Bermuda. } \\
\text { Whether age discrimination claims made in Europe sup- } \\
\text { ported claims against U.S. subsidiary of European corpo- } \\
\text { rate parent. }\end{array}$ \\
\hline Environmental law & & $\begin{array}{l}\text { Research of E.U. law regarding underground storage } \\
\text { tank. } \\
\text { Research of Canadian environmental regulations and } \\
\text { interpretation of policy coverage under Canadian law. } \\
\text { Representation of Japanese corporation in environmental } \\
\text { litigation in Pennsylvania state court. } \\
\text { Needed to advise clients on climate change issues influ- } \\
\text { enced by international law. }\end{array}$ \\
\hline Evidence & 1. & Whether attorney-client privilege exists in foreign jurisdic- \\
\hline
\end{tabular}




\begin{tabular}{|c|c|c|}
\hline & 2. & $\begin{array}{l}\text { tion and whether it applied in U.S. litigation to foreign- } \\
\text { made communication. } \\
\text { Whether evidenoe obtained by foreign governments can } \\
\text { be used in U.S. courts. }\end{array}$ \\
\hline Family law & 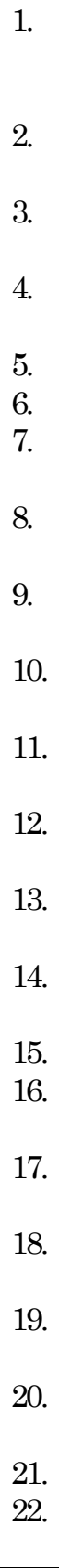 & $\begin{array}{l}\text { Researched on the impact of Shariala law on sale of a house } \\
\text { to a separated woman whose spouse lived in a country } \\
\text { that followed Islamic family law. } \\
\text { Research effect of foreign matrimonial law on U.S. immi- } \\
\text { gration status. } \\
\text { Research relating to marital status and rights and obliga- } \\
\text { tions regarding surrogacy and egg donation. } \\
\text { Whether family law of another country affects immi- } \\
\text { grant's eligibility for U.S. immigration. } \\
\text { Whether divorce documents from India were valid. } \\
\text { Whether Brazilian power of attorney was valid. } \\
\text { Research on enforcement of Pennsylvania custody } \\
\text { agreement in Brazil. } \\
\text { Research on rights of custodial parents to travel interna- } \\
\text { tionally. } \\
\text { Research on custody law where one parent took the chil- } \\
\text { dren to Switzerland. } \\
\text { Whether an immigrant was married under the domestic } \\
\text { law of the immigrant's country of origin. } \\
\text { Research on effect of Croatian divorce law on asylum } \\
\text { seeker. } \\
\text { Research on validity of prenuptial and postnuptial } \\
\text { agreements signed in foreign countries. } \\
\text { Research on application of the Hague Convention on In- } \\
\text { ternational Kidnapping to custody dispute. } \\
\text { Whether Pennsylvania divorce filing is affected by oppos- } \\
\text { ing party's filing in foreignjurisdiction. } \\
\text { Enforcement of support orders in foreignjurisdictions. } \\
\text { Research on rights of clients to relocate with children in- } \\
\text { ternationally. } \\
\text { Research on validity and effect of foreign marriages, di- } \\
\text { vorces, and adoptions on immigration clients. } \\
\text { Research on Bivens action concerning application of the } \\
\text { Hague Convention on international child abduction. } \\
\text { Research effect of foreign incarceration on client's hus- } \\
\text { band's duty of support and right to custody. } \\
\text { Research on the applicability of Geneva conventions to } \\
\text { annulments of forced marriages in India. } \\
\text { Research on effect ofSwiss law on unmarried fathers. } \\
\text { Whether Germany allows temporary alimony in order to } \\
\text { enforce a Pennsylvania order in Germany. }\end{array}$ \\
\hline
\end{tabular}




\begin{tabular}{|c|c|c|}
\hline & 25. & $\begin{array}{l}\text { Research on French pension rights for ex-spouse to de- } \\
\text { termine strategy in Pennsylvania divorce action. } \\
\text { Research on the difference between civil court and Rab- } \\
\text { binical court in Israel relevant to custody claim. } \\
\text { Research related to premarital agreements in various } \\
\text { foreign countries. }\end{array}$ \\
\hline Human rights law & 6. & $\begin{array}{l}\text { Whether there is a right to shelter or housing under in- } \\
\text { ternational law or U.S. treaty obligations. } \\
\text { Research of foreign law in human rights cases under U.S. } \\
\text { law, the Alien Tort Statute and the Anti-Terrorism Act. } \\
\text { Research on the validity of claims for recovery of assets } \\
\text { seized during World War II. } \\
\text { Research on how the UNHCR interprets the Refugee } \\
\text { Convention of } 1951 \text { and Protocol of } 1967 \text {. } \\
\text { Whether international treaties and conventions con- } \\
\text { demning torture support claim of prisoner who was as- } \\
\text { saulted by prison guard. } \\
\text { Research on right to reparations from Germany for senior } \\
\text { citizens. } \\
\text { Whether international treaty obligations to refugees sup- } \\
\text { port refugees' claim to SSI benefits. }\end{array}$ \\
\hline $\begin{array}{l}\text { Intellectual } \\
\text { property law }\end{array}$ & 2. & $\begin{array}{l}\text { Research on patent, trademark, and copyright laws of } \\
\text { various foreign countries. } \\
\text { Research on U.K. choice of law provision in patent licens- } \\
\text { ing agreement between U.S. and U.K. corporations. } \\
\text { Research on issues arising from computer network and } \\
\text { data security breaches including effect of foreign law on } \\
\text { foreign computer hackers, foreign corporations with } \\
\text { branches hacked in the U.S. and U.S. corporations with } \\
\text { branches hacked in foreign countries. } \\
\text { Research on foreign patent law relating to status of inven- } \\
\text { tor. } \\
\text { Research on requirements for filing of patents and } \\
\text { trademarks abroad and on effect of foreign litigation. } \\
\text { Research on legal standards for patentability in Japan } \\
\text { and patent procedure in Canada. } \\
\text { Management of IP portfolio requires constant contact } \\
\text { with foreign firms and foreign laws and research on cli- } \\
\text { ents' issues concerning infringement, and effect of treaties } \\
\text { and conventions relating to trademarks and copyright. } \\
\text { Research on the enforceability of software license contract } \\
\text { in Saudi Arabia and in U.S. under Saudi law and the ef- } \\
\text { fect of specifying jurisdictions and venue in Saudi Arabia } \\
\text { for matters under the license agreement. } \\
\text { Handling of multiple international deals involving music }\end{array}$ \\
\hline
\end{tabular}




\begin{tabular}{|c|c|c|}
\hline & 13. & $\begin{array}{l}\text { and video licenses which require research into interna- } \\
\text { tional copyright, trademark, tax, and contract law. } \\
\text { Research on Israeli law prohibiting sale of Israeli-funded } \\
\text { software to non-Israeli entity. } \\
\text { Research on E.U. privacy issues and tax issues in MDA } \\
\text { and technology transfer across borders. } \\
\text { Research on ICC arbitrations for breach of a trademark } \\
\text { licensing agreement between a Swiss company and a } \\
\text { U.S. company. } \\
\text { Research of international charters controlling essential } \\
\text { amino acids, computer technology, and pharmaceuticals. }\end{array}$ \\
\hline Insurance & 1. & $\begin{array}{l}\text { Research of U.K. law regarding deposition in U.K. of U.K. } \\
\text { insurance organization. } \\
\text { Research on insurance coverage in foreign jurisdictions } \\
\text { and foreign law on construction of insurance policies. }\end{array}$ \\
\hline International trade & 5. & $\begin{array}{l}\text { Research on increased duty assessment in E.U. on goods } \\
\text { produced in U.S. and Korea. } \\
\text { Development of contract for distribution of goods in Eu- } \\
\text { rope and Canada that allows U.S. company to minimize } \\
\text { duties assessed on European and Canadian customers. } \\
\text { Research on U.S. company sales in Mexico to invoke ben- } \\
\text { efit ofTrade Agreements. } \\
\text { Research on structuring trade so that the royalties paid } \\
\text { by U.S. company to Japanese company are not added as } \\
\text { partof the value of the goods then imported to Canada. } \\
\text { Research on NAFTAclaim. }\end{array}$ \\
\hline Labor law & $\begin{array}{l}1 . \\
2 .\end{array}$ & $\begin{array}{l}\text { Research on Chinese law on reduction in force. } \\
\text { Research on independent contractor agreements under } \\
\text { Hong Kong law. } \\
\text { Research on application of U.S. law to non-U.S. citizen } \\
\text { living abroad. } \\
\text { Research on employment and labor law of Canada and } \\
\text { New Brunswick province in connection with representa- } \\
\text { tion of an international labor union with a local in Cana- } \\
\text { da. } \\
\text { Research on Mexican labor protection laws and whether } \\
\text { they can be used to protect low wage workers from Mexi- } \\
\text { co in U.S. actions. } \\
\text { Whether labor agreement that was signed in France and } \\
\text { incorporated terms and conditions in the U.S. and in in- } \\
\text { ternational treaties created obligations enforceable in the } \\
\text { U.S. }\end{array}$ \\
\hline Maritime law & 2. & $\begin{array}{l}\text { Research on U.K. law which is precedential in maritime } \\
\text { matters. } \\
\text { Research on applicability of foreign and domestic law in }\end{array}$ \\
\hline
\end{tabular}




\begin{tabular}{|c|c|c|}
\hline & 3. & $\begin{array}{l}\text { personal injury cases of seamen. } \\
\text { Research on foreign law relevant to foreign charter parties } \\
\text { and bills of loading and advising foreign clients about U.S. } \\
\text { admiralty law. }\end{array}$ \\
\hline $\begin{array}{l}\text { Personal injury } \\
\text { law }\end{array}$ & $\begin{array}{l}8 . \\
9 . \\
10 . \\
11 . \\
12 . \\
13 . \\
14 . \\
15 .\end{array}$ & $\begin{array}{l}\text { Research on the Warsaw Treaty's application to claim of } \\
\text { injury from thrombosis on airline flight. } \\
\text { Research on statute of limitations of Scotland in repressed } \\
\text { memory case. } \\
\text { Research on U.S. and U.K. insurance law related to oil } \\
\text { platform explosion in the North Sea. } \\
\text { Research on issues in lawsuit of woman injured in camel } \\
\text { ride to which she was referred by Cairo Marriott hotel } \\
\text { employee. } \\
\text { Research on effect of criminal and civil laws of European } \\
\text { countries on a defective product claim. } \\
\text { Research on Canadian and U.S. tort law relevant to rep- } \\
\text { resentation of Canadian truck companies and drivers in- } \\
\text { volved in accidents in the U.S. } \\
\text { Research on personal jurisdiction and choice of law issues } \\
\text { arising in claim of beating of U.S. citizen in Cancun hotel } \\
\text { room. } \\
\text { Research on German law applicable to risk management } \\
\text { program in Germany. } \\
\text { Representation of plaintiff in suit against Iran. } \\
\text { Research on statute of limitations and wrongful death } \\
\text { actions in Mexico. } \\
\text { Research on consumer product safety law in the U.K. } \\
\text { Research on libel laws in other jurisdictions. } \\
\text { Research on international treaties relating to airline tort } \\
\text { claims. } \\
\text { Research on defamation claims of U.S. citizen against a } \\
\text { Russian media conglomerate. } \\
\text { Whether identical case brought in Israel barred U.S. } \\
\text { products liability case under res judicata. }\end{array}$ \\
\hline Procedural law & $\begin{array}{l}1 . \\
2 .\end{array}$ & $\begin{array}{l}\text { Whether Canada recognized "first file" rules where Ca- } \\
\text { nadian suit was preceded by U.S. litigation. } \\
\text { Research on proper service and translation of complaint } \\
\text { into Italian and German for service on foreign corpora- } \\
\text { tions. } \\
\text { Research on service on foreign company in conformity } \\
\text { with Hague Convention. } \\
\text { Research on French law to determine viability of making } \\
\text { claims for injunctive relief in U.S. courts in dispute be- } \\
\text { tween U.S. company and French company. } \\
\text { Research on effect of Japanese privacy laws on docu- }\end{array}$ \\
\hline
\end{tabular}




\begin{tabular}{|c|c|c|}
\hline & $\begin{array}{l}16 . \\
17 . \\
18 . \\
19 . \\
20 . \\
21 . \\
22 .\end{array}$ & $\begin{array}{l}\text { ments produced in U.S. litigation. } \\
\text { Research on service of process on foreign entity. } \\
\text { Research on enforceability of U.S. judgment abroad and } \\
\text { on foreign rules of personal jurisdiction over U.S. entity. } \\
\text { Research on foreign law applicable to service of process } \\
\text { overseas for claimsin domestic bankruptcy. } \\
\text { Research on civil procedure in Chile and Mexico. } \\
\text { Research on service of process under Hague Convention } \\
\text { on foreign entities. } \\
\text { Research on the validity of a judgment under Indonesian } \\
\text { law and whether the judgment should be afforded comity } \\
\text { in the U.S. } \\
\text { Research on validity of foreign arbitration award in the } \\
\text { U.S. } \\
\text { Research on service of process and discovery rules in other } \\
\text { nations. } \\
\text { Whether claim of Italian company against German com- } \\
\text { pany could be brought in the U.S. based on activities of } \\
\text { U.S. subsidiary. } \\
\text { Research on variations in privileges across countries, reg- } \\
\text { ulatory implications abroad of domestic actions, and ef- } \\
\text { fects of foreign consent decrees on domestic matters. } \\
\text { Research on forum non conveniens and Rule } 19 \text { dismissal } \\
\text { where alternate forum was India. } \\
\text { Research on Canadian discovery procedures relevant to } \\
\text { national class action. } \\
\text { Research on U.K. and Hague discovery procedures and } \\
\text { U.K. substantive law relevant to claim of negligence and } \\
\text { misrepresentation against U.K. insurance broker. } \\
\text { Research on Hague service issues relevant to lawsuit in } \\
\text { U.S. against Polish company. } \\
\text { Research on personal jurisdiction over Italian national } \\
\text { resident in Italy and served according to the Hague con- } \\
\text { vention. } \\
\text { Research on whether U.S. corporation was subject to arbi- } \\
\text { tration of employment disputein Canada. } \\
\text { Research on whether U.S. has personal jurisdiction over } \\
\text { U.K. corporation used as agent to commit torts in NY. }\end{array}$ \\
\hline Tax law & 2. & $\begin{array}{l}\text { Research on tax consequences of lien and guaranty laws } \\
\text { of multiple foreign jurisdictions on international fi- } \\
\text { nancings. } \\
\text { Research on applicability of foreign estate and inheritance } \\
\text { taxes on awards from the } 9 / 11 \text { Victims' Compensation } \\
\text { Fund. } \\
\text { Research on German tax law relevant to purchase of in- }\end{array}$ \\
\hline
\end{tabular}




\begin{tabular}{|l|r|l|}
\hline & $\begin{array}{l}\text { terest in a real estate project in Germany. } \\
\text { 4. }\end{array}$ \\
Research on foreign tax law relevant to mergers and ac- \\
quisitions deals.
\end{tabular}




\begin{tabular}{|c|c|c|}
\hline Miscellaneous & $\begin{array}{l}1 . \\
2 . \\
3 .\end{array}$ & $\begin{array}{l}\text { Whether French national living in U.S. could legally do- } \\
\text { nate to French political candidates. } \\
\text { Research on E.U. rules prohibiting certain individuals } \\
\text { from visiting E.U.countries. } \\
\text { Research on E.U. regulatory framework for conducting } \\
\text { clinical trials. } \\
\text { Research on client's acquisition of property in Mexico. } \\
\text { Research on validity of RICO claim which depended on } \\
\text { knowledge of whether there was underlying illegal activi- } \\
\text { ty based on another country's law. } \\
\text { Whether the immigration laws of another country offer } \\
\text { clients opportunities for immigration that are not availa- } \\
\text { ble in the U.S. } \\
\text { Research of foreign and international law on labor, em- } \\
\text { ployment, property, lobbying, government ethics, insur- } \\
\text { ance, and cultural heritage laws arising in arts related } \\
\text { law practice. } \\
\text { Research on applicability of U.S. law to a consulate. }\end{array}$ \\
\hline
\end{tabular}

